\title{
A SZAJKÓ (Garrulus glandarius) KEZELÉSI TERVE MAGYARORSZÁGON
}

\author{
Faragó Sándor \& Hajas Péter Pál \\ Soproni Egyetem, Vadgazdálkodási és Gerinces Állattani Intézet \\ University of Sopron, Institute of Wildlife Management and Vertebrate Zoology \\ H-9400 Sopron, Bajcsy-Zs u. 4., Hungary \\ E-mail: farago.sandor@uni-sopron.hu; pphajas@eco-seed.eu
}

FARAGÓ S. \& HAJAS P. P. (2019): MANAGEMENT PLAN FOR EURASIAN JAY (Garrulus glandarius) IN HUNGARY. Hungarian Small Game Bulletin 14: 93-122. http://dx.doi.org/10.17243/mavk.2019.093

\section{A SZAJKÓ (Garrulus glandarius) BIOLÓGIÁJA ÉS ÖKOLÓGIÁJA, A KEZELÉSI GYAKORLAT ÉRTÉKELÉSE}

\subsection{BEVEZETÉS}

A Magyarországon vadászható szajkó Európában stabil $(\mathrm{S})$ állományú faj (TUCKER \& HEATH 1994), szerepel a Berni Egyezmény III. Mellékletében és az EU Madárvédelmi Irányelvek II/2 Mellékletében (FARAGÓ 2015).

A szajkó vadfaj státusát kizárólagosan a madárfészkekben okozott kártételére hivatkozó, évszázados vadászati hagyományokra vezetjük vissza. Arra az időre, amikor a madarak káros, vagy hasznos volta volt elsősorban vadászhatóságuk alapvető szempontja.

SzÉCSI (1892) írja: „A mátyás tápláléka igen különféle. Mogyoró, tölgy-és bükkmakk, fenyömag, cseresznye, puha gyümölcs, hernyó, itt-ott egér is, de kivált a madarak tojásai s fiókái, melyek felkeresésében még csak a szarka éri utól. Egész nap a fákon, ágról-ágra ugrándozik, onnan le a földre s a sürü bokrot átkutatva lehetetlen, hogy valamely fészek figyelmét kikerülje. Innét van, hogy a hol nagyobb számban tartózkodik, onnan minden apró madár eltünik. A szajkó tehát minden alkalommal és móddal pusztítandó.'

CHERNEL (1899) szerint „Valóságos szemfényvesztö, csaló. Nyilvánosan, a világ elött, legjobb tulajdonait fitogtatja, mert alattomban, elpalástolva folytatja vérengzéseit $s$ nem annyira közvetlenül, mint közvetve árt nekünk, ámbár helyenként közvetlenül is (makk-, gyümölcs-, pusztitás, fáczántenyésztés megrontása.) Csak éleszemü, tapasztalt megfigyelök, kiket a fölületesség szine-mázza csalódásba nem ejt, tudják, micsoda lelketlen, vérengzö gyilkolója ö a leghasznosabb apró madaraknak. Költés szakában fészket fészek után foszt ki, nem válogat tojás, madárfiók között, sőt az öregeket is megtámadja, még a rigóval, s pár napos nyulacskával is megbirkózik. Nemcsak a magevö madarak, hanem különösen a poszátafélék, czinegék, harkályok, légykapók, fülemilék, rigók stb. szaporodását hátráltatja igy. Tágabb odvakban költö madárfajok magzatait, ha eléri, csak úgy kirabolja, mint az öszapó fészkét, melyet egyszerüen szétszaggat.

Vele úgy vagyunk, hogy a külszín csalóka benyomása kápráztat meg. A való megismerése azonban a dolgok mélyéböl meriti itéletét, $s$ ez esetben nem a szajkó javára. Nem érdemli kíméletünket, hanem inkább, hogy méreggel pusztítsuk, fészkeit megrongáljuk, a lövést pedig ne sajnáljuk töle."

HERMAN (1901) szerint „... zajgó úr őkegyelme még gébicsnél, szarkánál is nagyobb fészekrabló. Tojás, meztelen madárporonty, a fészek szélén üldögélö és anyját váró tokos poronty, az mind Mátyás úr prédája.”. „Szóval nagyon káros, és nem ajánlható kegyelemre.” 
LOVASSY (1927) szerint „Bár sok rovart tönkre tesz, mégis mint a makktermés kárositója s mint bizonyos hasznos madárfajok fészkének egyik legföbb pusztítója, az erdöre túlnyomóan kártékony. Egyetlen szajkópár több madárfészket elpusztít, mint a környék összes gyerköce. Kártételéböl részesedik a gyümölcstermesztő, a mezögazda és a vadtenyésztö is. Lövéssel és fészkei elpusztitásával gyérithetö."

NEMESKÉRI KISS et al. (1942) értékelése szerint „Fácánosokban nem szabad megtürni, mert sok tojást pusztít el. Irtandó ott is, ahol császármadarak vagy fajdok vannak, mert ezeknek tojásait is pusztitja".

PÁTKAI (1971) az újabb kor szemlélete, a biológiai növényvédelem szerint ítéli meg. „A vadgazdának nem okoz számottevő kárt, viszont fészekrabló tevékenysége sok rovarirtó madarunk állományát apasztja." Direkt nem ítéli el zsákmányolását, de igazolva látja vadászható faj létét.

FARAGÓ (2015) szerint "Fészekfosztogatása közismert, föként erdei énekesmadarak de újabb megfigyelések szerint (VARGA, 1994) pl. a holló (Corvus corax) - tojásai és fiókái képezhetik táplálékát, ezért elsősorban természetvédelmi érdekböl szükséges gyérítése."

Ez a pusztítandó-irtandó-lövendö-gyérítendö nézet kíséri végig napjaikig a szajkó megítélését.

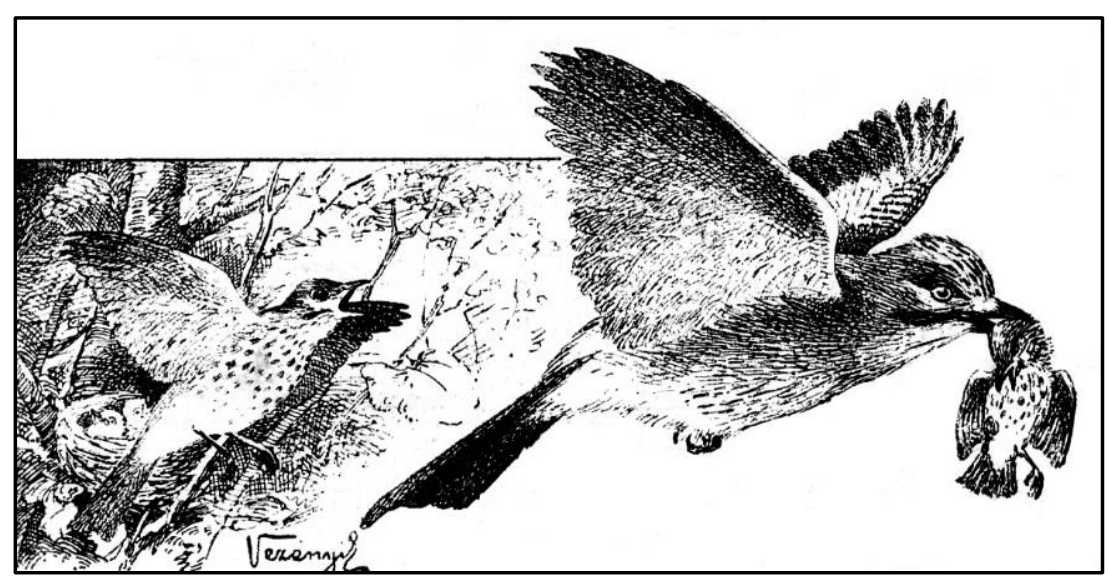

A szajkó korábban - „káros” volta okán - egész évben vadászható volt Magyarországon, amit az EU madárvédelmi irányelv - fészkelő populáció védelme - alapján július 1. - február 28 (29). közti időszakra kellett módosítani. E változás következményei jelentősek lennének különösen a természetvédelem számára - a faj madárfészekben okozott kártétele miatt -, de a vadászati rendelet, apróvadas vadászterületeken, az apróvad szaporodási időszakában, a vadászati hatóság külön engedélyéhez kötve lehetővé teszi gyérítését. Természetvédelmi szempontból is indokolt állományának alacsony sürüségen való tartása.

\section{2. ÖKOLÓGIA}

\subsection{1. Élőhelyi feltételek}

Síksági, domb- és hegyvidéki lomberdők, elegyes állományok lakója. Kedveli, és előnyben részesíti a tölgyeseket, csereseket és bükkösöket, vagy e fafajokkal elegyes erdőket. Olykor fenyvesekben is elöfordul. Megtelepszik ártéri és galériaerdőkben, arborétumokban, városszéli parkokban is. Vonulása, vagy rövidtávú migrációja során megjelenhet a fenti tipikus területektől eltérő élőhelyeken, így pl. az erdősávokban is. 


\subsubsection{Szaporodás}

Ivarérettség: Első éves korban ivarérett.

Ivari kapcsolata: Monogám, a szezonális párkapcsolat jellemzi. A párképzés tavasszal gyakran a szajkók lármás gyülekezésével indul. Ezt azonnal az udvarlás követi, ami udvarlóetetéssel jár együtt. A párba állás olyan hosszú ideig elhúzódhat, hogy a szajkók csapatai vonulásban lehetnek még, amikor mások már költenek. Ebböl következik, hogy északi alfajokból egyes párok hátra maradhatnak, illetőleg a déli populációk szajkóit északra, vagy más irányba vonuló madarak magukkal ragadhatják (KEVE 1995).

Költési idő: A fészeképítés kezdete legkorábban március közepén indulhat, amit összefüggésbe hoznak a lombosodással. A tojásrakás az időjárástól függően április végén kezdődhet és Közép-Európában május végéig, ritkán június közepéig tarthat (MAKATSCH 1976). Hazai viszonyok között ettől eltérő eredményeket kapott HARASZTHY (2019), aki 192 fészekalj gyüjtési ideje alapján az alábbi költési időszakot határozta meg. Április 1-10: 2; április 11-20: 40; április 21-30: 86; május 1-10: 40; május 11-20: 16; május 21-31: 6 . További 1-1 fészekalj származott június 10. és június 12. i dátummal. A május 10 utáni fészekaljakat nagy valószínüséggel sarjúfészkeknek tartotta. A költés az ország déli részén előbb kezdődik, mint az északi felében.

A fészek helye: A fészek erdőben és erdőszélen, olykor odúban vagy sziklarepedésben, rendszerint azonban bokron vagy fán van. Az alkalmas fészkelöhely által meghatározott módon az erdő belsejében magasabban, a széleken vagy nyiladék mellett alacsonyabban fészkel. Településeken, elsősorban külvárosokban, villanegyedekben, sőt esetenként épületeken (FESTETICS 1954) is fészkel. Fészkelhet mesterséges fészekodúban is (MAKATSCH 1976). Erdélyben vizsgált szajkófészkek $(n=41)$ tartófái az alábbiak voltak: vadkörte -12 fészek (29\%) (Pyrus pyraster), kocsánytalan tölgy és gyertyán - 9-9 fészek (22-22\%), csíkos kecskerágó (Euonymus europaeus) - 5 fészek (12\%), füz (Salix spp.) - 2 fészek (5\%), valamint erdei iszalag (Clematis vitalba), erdei fenyő, kislevelü hárs (Tilia cordata) és egybibés galagonya (Crataegus monogyna) - 1-1 fészek (összesen 10\%). A fészkek magassága 4,14 (1,2-8,5) cm volt, amelyek közül 19 (46,3\%) D-i, 5 (12,5\%) É-i, 4-4 fészek (9,7-9,7\%) pedig K-i, Ny-i, DNy-i és DK-i, illetve 1 fészek $(2,4 \%)$ ÉK-i tájolású volt. A fészkek legtöbbje (50\%) cserjék koronájában, ágak elágazásánál, másik nagy csoport esetében (30\%) fák törzsének elágazásában, kisebb arányban (15\%) több ág találkozásánál, illetve fák vagy cserjék fiatal ágai között (5\%) épült (KORODI GÁL 1972). Magyarországon gyüjtött ismert tartó-fájú - szajkó fészekaljak $(n=74)$ tartó-fa és cserje fajai az alábbiak voltak: kocsánytalan tölgy - 15 fészek $(20,3 \%)$, gyertyán -8 fészek $(10,8 \%)$, erdei fenyő, cser és kocsányos tölgy - 7-7 fészek (9,5-9,5\%), törékeny füz (Salix fragilis) - 6 fészek $(8,1 \%)$, vadkörte és fekete fenyö - 5-5 fészek (6,8-6,8\%), csere galagonya (Crataegus oxyacantha) 4 fészek $(5,4 \%)$, akác - 2 fészek (2,7\%), valamint mezei szil (Ulmus minor), közönséges boróka (Juniperus communis), bükk, füz (Salix spp.), húsos som (Cornus mas), mezei juhar (Acer campestre), virágos köris (Fraxinus ornus) és sziklafal (!) 1-1, összesen 8 fészek $(10,4 \%)$. A fészkek (n=74) magassága: $4,9(0,6-14,0)$ m volt (FARAGÓ 2001a). TÖRÖK (2000) szerint tölgyesekben, fenyvesekben általában 4-6, ritkábban 10-12 m magasan, a fák törzséhez közel építi fészkét. Erdőszélen, nyíltabb területeken, inkább cserjéken, rendszerint 2-3 méter, ritkán $0,5 \mathrm{~m}$ magasan rakja meg fészkét.

Fészke: A fészek helyét a tojó és a hím közösen választják, de a hím szerepe nagyobb (TÖRÖK 2000). Mindkét szülő részt vesz a fészekanyag gyüjtésében és az építésben (TÖRÖK 2000), a hím inkább kezdetben és a fészek feldíszítése során aktív. A fészkek építése KORODI GÁL (1972) szerint 6-9 napig tart. A fészek átméröje 25-30 cm, magassága 14-16 cm, a fészekcsésze átmérője $12 \mathrm{~cm}$, mélysége $6 \mathrm{~cm}$ (MAKATSCH 1976; GLUTZ \& BAUER 1993). Erdélyben vizsgált fészkek átlagos magassága $19 \mathrm{~cm}$, átmérője $22 \mathrm{~cm}$, a fészekcsésze 
átmérője $15 \mathrm{~cm}$, mélysége $6,5-7 \mathrm{~cm}$, anyagának vastagsága $1,5-2 \mathrm{~cm}$ volt. A fészkek $(\mathrm{n}=40)$ váza $131 \mathrm{~g}$, a finom gyökérkékből és füfélékből készült csésze 21,5 g-ot nyomott (KORODI GÁL 1972). Saját fészek építése mellett Karancslapujtő határában (1994. április 17.) megfigyelték szarkafészekben történt költését is (ROZGONYI 1994).

Tojásrakás, költésszám: A tojó általában naponként, rendszerint a reggeli (4-8 óra között), ritkán a délutáni (16-19 óra között) időszakban helyezi a fészekbe az új tojásokat. A megfigyelhető legrövidebb intervallum 2 tojás lerakása között 19 óra, a legnagyobb 30 óra volt (KORODI GÁL 1972). Évente egyszer költ, fészekpusztulás esetén sarjúfészkelése általános.

A fészekalj nagysága: (3-)5-6(-8) tojás (HARRISON 1975), 5-7(-10) tojás (MAKATSCH 1976), 4-7(-8) tojás (GLUTZ \& BAUER 1993), 5-6 tojás (TöRÖK 2000), 5-7 tojás (HARASZTHY 2019). Magyarországon gyüjtött 92 fészekalj közül 4 tojás 1 esetben $(1,1 \%), 5$ tojás 28 esetben $(30,4 \%), 6$ tojás 44 esetben $(47,8 \%), 7$ tojás 14 esetben $(15,2 \%), 8$ tojás pedig 5 esetben $(5,4 \%)$ fordult elő. Az átlagos fészekalj nagyság 5,9 tojás volt (FARAGó 2001a). Erdélyben KORODI GÁL (1972) 19 fészekből 10 fészekben $(52,6 \%) 6$ tojást, 7 fészekben $(36,8 \%) 5$ tojást, 2 fészekben $(10,6 \%) 7$ tojást talált, az átlagos fészekalj nagyság 5,7 tojás volt. Csehországban utóbbi érték (FOLK, idézi GLUTZ \& BAUER 1993) M69: 5,91 tojás/fészekalj volt

A tojások alakja oválistól a rövid oválisig, vagy hegyes oválisig terjedhet, fénytelenek, színük szürkés vagy kékeszöldes, illetve homokszínü vagy olívzöld alapon világos barna pettyekkel, foltokkal tarkítottak oly módon, hogy első látásra szinte egyszínünek látszanak. A G. g. glandarius tojásméretei: 30,6 × 22,6 mm (HARRISON 1975), közép-európai gyüjtésből $\mathrm{D}_{143}: 31,40 \times 23,24$ tömege: 8,4 gramm. Csehországi adatok szerint $\mathrm{D}_{252}: 32,0 \times 22,87 \mathrm{~mm}$ (TOUFAR, idézi GluTZ \& BAUER, 1993), erdélyi fészekaljak alapján $\mathrm{D}_{70}: 32,1 \times 23,3 \mathrm{~mm}$ (KORODI GÁL 1972). Magyarországon mért tojások $(n=546)$ jellemző értékei az alábbiak voltak (FARAGÓ 2001a).

$$
\begin{array}{ll}
\mathrm{D}_{546}: & 30,70 \times 22,77 \mathrm{~mm} \\
\mathrm{H}_{\min } . & 27,30 \times 21,20 \mathrm{~mm} \\
\mathrm{Sz}_{\min } . & 31,55 \times 20,20 \mathrm{~mm} \\
\mathrm{I} & 1,349 \\
\mathrm{I}_{\min } & 1,16
\end{array}
$$

$$
\begin{array}{ll}
\mathrm{H}_{\max } . & 35,30 \times 22,50 \mathrm{~mm} \\
\mathrm{H}_{\max } & 34,10 \times 26,00 \mathrm{~mm} \\
\mathrm{I}_{\max } & 1,57
\end{array}
$$

Kotlás: A kotlás akkor kezdődik, amikor a tojó lerakta a 3-4. tojását (KORODI GÁL 1972). MAKATSCH (1976) feltételezi, hogy a kotlás megkezdésében nagy egyedi eltérés mutatkozhat, azaz kezdődhet az első, vagy éppen az utolsó tojás lerakása után is. A kotlás 16-17 napig tart (MAKATSCH 1976, TÖRÖK 2000). KORODI GÁL (1972) által vizsgált fészkek 92\%-ában 16 napig, 8\%-ában 17 napig tartott a kotlás. Mindkét szülő kotlik. A kelés 24-30, olykor 56 óra alatt történik meg (KORODI GÁL 1972), általában jó eredménnyel, terméketlen tojás csak nagyobb tojásszámú fészekben van. TöRÖK (2000) szerint nem szinkronizált a kelés, hanem a tojások lerakásának sorrendjében kelnek ki a fiókák.

Fiókanevelés: A fiatalokat mindkét szülő eteti. Rendszerint 20-22 napos, de zavarás esetén már 17 napos korban, repülőképességük elérése előtt is elhagyhatják a fészket. A szülök további 3-4 héten keresztül vezetik a fiatalokat (KORODI GÁL 1972; GLUTZ \& BAUER 1993; TÖRÖK 2000).

Költési eredmény, halandóság, életkor: A fészkekben mókus, pelék és szarka tudnak akár 50\%-ot meghaladó kárt tenni, már a tojásos állapotban. KORODI GÁL (1972) által Erdélyben vizsgált 41 fészekből $22(56,3 \%)$ még kelés előtt elpusztult. A pusztulás okai az alábbiak voltak; mókus: 8 fészekalj, gyerekek vagy kirándulók: 7 fészekalj, pele-félék: 3 fészekalj, szarka: 2 fészekalj, másik szajkó: 2 fészekalj. A halandóság - 103, fióka korban meggyürüzött 
közép-európai madár alapján - fiatal korban igen magas volt, 73,7\%-uk még születésük évében elpusztult (PUTZIG, idézi GLUTZ \& BAUER 1993). A legmagasabb ismert korú szajkó 18 évet élt (GLUTZ \& BAUER 1993).

\subsubsection{Táplálkozás}

A szajkó táplálékát a talajfelszínről a lombkoronaszintig gyüjti. Mindenevő, de a szaporodási időszakban elsősorban állati táplálékon él, illetve azzal eteti fiókáit. A fiókák táplálékában tömegviszonyok alapján a gerinctelenek dominálnak (96,9\%), 1,5\%-ot tesznek ki a gerincesek, 1,9\% a növényi rész és $1,2 \%$ a szervetlen anyag. A gerinctelenek közül dominánsak a lepke hernyók (81\%), fontosak a bogarak (9\%) és vannak a táplálékában pókok (3\%), csigák (1\%) és egyéb ízeltlábúak (1\%) is (KORODI GÁL 1972). Hasonló eredményt közöl TÖRÖK (2000) egy cseres-tölgyesben végzett vizsgálat során. A zsákmányállatok $(\mathrm{n}=255)$ főként hernyók (kis téliaraszoló, fésűs bagolylepkék, őszi kékesbagoly, púposszövők, fahéjszínü bagolylepke), pókok (zöld keresztes pók, karolópókok, torzpók), bogarak (futóbogarak, gyalogcincérek, májusi cserebogár, ormányosbogarak) voltak. Táplálékában, kisebb mennyiségben előfordultak csigák, sáskák, kétszárnyúak, hártyásszárnyúak és kabócák is. Gerincesek közül a mezei pockot, a fekete és az énekes rigó tojásait, illetve tokos fiókáit említi TÖRÖK (2000). CSIKI (1913) magyarországi szajkók (n=327) gyomrában az állati táplálék között legnagyobbrészt rovarokat, leginkább - 186 esetben - bogarakat (Coleoptera), mégpedig futóbogarakat (Carabidae) 36 esetben, ganéjtúró bogarakat (Scarabaeidae) 27 esetben, májusi cserebogarat (Melolontha melolontha) 32 esetben, aranyos rózsabogarat (Cetonia aurata) 18 esetben, ormányos bogarat (Curculionidae) 124 esetben, cincéreket (Cerambycidae) 19 esetben talált. Egyéb rovarok közül a hangyák, darazsak, lepkebábok és hernyók, szitakötők, tücskök, sáskák, szöcskék, poloskák, valamint százlábúak, pókok és csigák is előfordultak táplálékában. A tavaszi/nyári gyomrokban $(n=75)$ mindössze 2 esetben lehetett madármaradványt kimutatni. Hasonlóan e vizsgálathoz, mindössze 1 esetben talált madártojás maradványokat VASVÁRI (1933) is szajkók gyomrában. KEVE \& STERBETZ (1968) vizsgálatai szerint a felnőtt madarak $(\mathrm{n}=372)$ nyári táplálékában uralkodtak az ízeltlábúak, 121 taxont sikerült kimutatniuk. Leggyakoribbak a bogarak (Coleoptera) voltak, közülük is kiemelkedően sok gabonafutrinkát (Zabrus tenebrioides - 32 gyomor, 145 pd), kerti cserebogarat (Phyllopertha horticola - 11 gyomor, 90 pd), májusi cserebogarat (Melolontha melolontha -31 gyomor, $51 \mathrm{pd}$ ) fogyasztottak. A bogarak mellett néhány egyenesszárnyút (elsősorban tücsköket - 24 gyomor, 30 pd), fülbemászókat (7 gyomor, 16 pd), kevés lepkét, szitakötöt, vaspondrót (Julus spp.) zsákmányoltak. A hártyásszárnyúak közül csak lóhangyákat (Camponotus ligniperda, C. vagus - 17 gyomor, 25 pd) ettek, s 43 gyomorban (51 pd) darazsak is voltak. Gerincesek közül csak 22 Microtus spp., 8 Muridae spp. és 6 kis énekes madár maradványát (csont, ill. toll) lelték meg. Az állati eredetủ zsákmány mellett 84 mag, illetve alkalomszerüen felvett növényi rész szerepelt a tápláléklistán. Leggyakoribb a makk volt (76 gyomor - 23,2\%), az követte a kukorica (23 gyomor - 7\%), majd Rubus, Prunus, Sambucus termések, ill. magvak, gabonaszemek, egy gyomorban $1 \mathrm{db}$ Potamogeton mag, illetve egy másikban $216 \mathrm{db}$ vadmuhar mag. A felnőtt madarak $(\mathrm{n}=413)$ téli táplálékát vizsgálva 174 gyomorban (42,1\%) ill. valószínüleg további 145 gyomor meghatározhatatlan maradványaiban fordult elő a tölgymakk, 178-ban $(43,1 \%)$ a kukoricaszem. Egyéb táplálékfajok (Polygonum spp., Setaria spp., Sambucus ebulus, Atriplex spp., Robinia pseudoacacia, búza, árpa, zab, rizs) viszonylag kis szerepet játszottak. Ebben az évszakban az ízeltlábú táplálék (Forficula auricularia, Gryllus campestris, Cleonus cinereus) jelentéktelen. CHERnel (1921) szelídgesztenye (Castanea sativa), SzEMERE (1957) gomba (Boletus luteus és Tuber spp.), TÖRÖK (2000) alma, mandula, dió fogyasztását írta le. 
A makkokat - valószínűleg tárolási céllal - az avarba rejtve, majd arról elfeledkezve, a szajkó elősegíti a tölgyesek, bükkösök természetes felújulását, vagy mesterséges erdők természetes átalakulását (SZEKRÉNYES 2013).

Már korábban is megállapították, hogy egyes években (talán kis makktermés idején) előtérbe került a kukorica, mint táplálék (KEVE, 1995). A vaddisznószórók folyamatos üzemeltetésével ez a táplálékforrás napjainkban adott az erdők belsejében is. Ezt a szajkók felismerték, és rá is járnak a szórókra. 2019/2020 telén, erős szajkóvonulás mellett a LAJTA Projectben a lábon álló kukorica, szajkók általi cső „fosztogatását” lehetett megfigyelni.

\subsection{ELTERJEDÉS}

A szajkó palearktikus elterjedésű, politipikus faj. Több tucat alfaj között megoszló areája egész Európára (1-2. térkép), Észak-Afrikára, Kis-Ázsiára, a Közel-, ill. KözépKeletre, a szibériai tajga régióira, Japánra és Szahalinra, Kínára, Hátsó-Indiára és a Himalájára terjed ki. Klinálisan eloszló alfajait morfológiai-leszármazási bélyegek alapján több alfajcsoportra osztják.

Első ismertetésünkben a KEVE (1995) féle besoroláshoz tartjuk magunkat, kiegészítve GLUTZ (1993) összefoglalásával, illetve a földrajzi elterjedési körzeteket alapul véve.

Ezt követően MADGE (2017) legújabb listáját is megadjuk azzal a megjegyzéssel, hogy egész régiók (Himalája vidéke, Dél-Kína, Tajvan, Hátsó-India stb.) maradtak ki abból, az imént idézett KEVE-GLUTZ féle felsorolásokhoz viszonyítva.

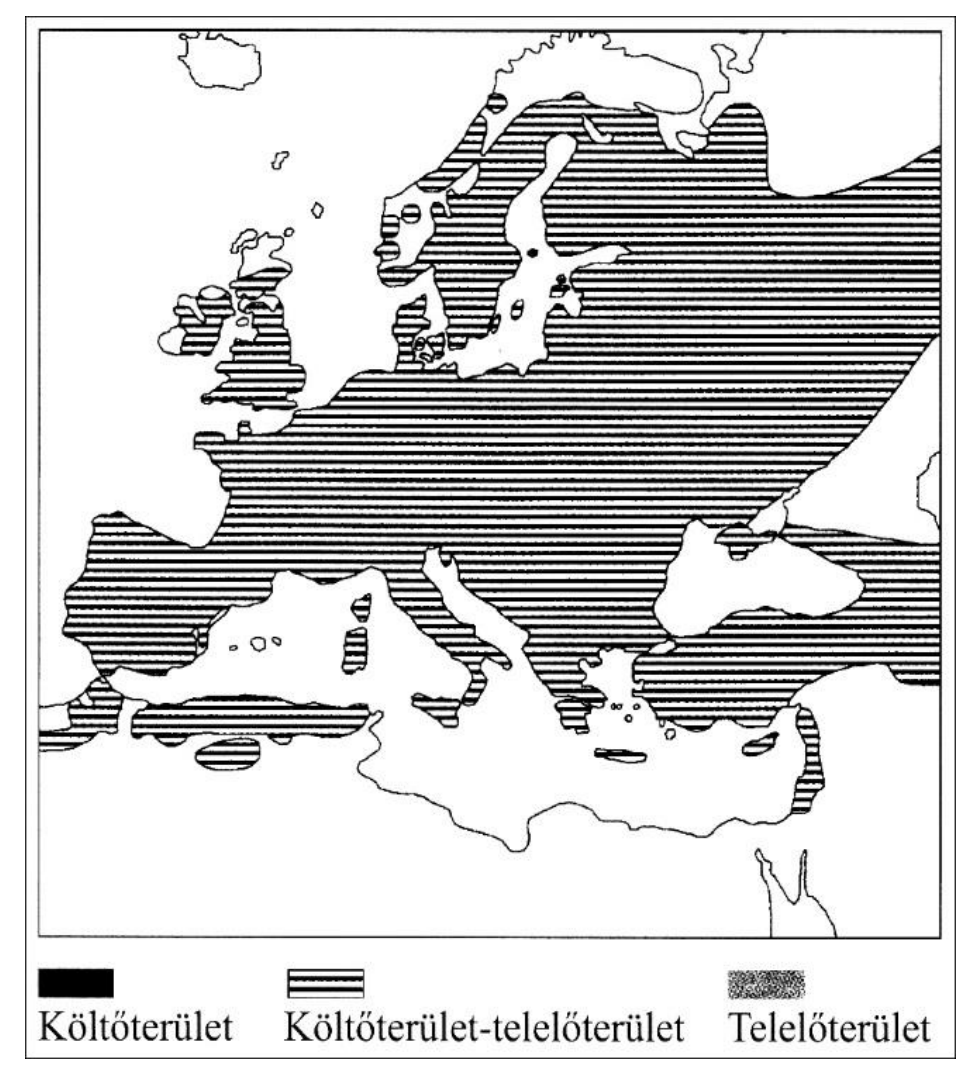

1. térkép: A szajkó elterjedése Európában (JONSSON, 1993)

Map 1: Distribution of Eurasian Jay in Europe (JONSSON 1993)

(A) Glandarius-alfajcsoport: a fejtető fehér alapon feketén sávozott, csak egyszerü kék-fekete-fehér szárnytükrük van. (1) glandarius: Közép-és É-Európa, (2) rufitergum: Anglia, Wales, D-Skócia, (3) hibernicus: Írország, É-Skócia, (4) armoricanus: ÉNy-Franciaország, (5) fasciatus: Spanyolország, (6) corsicanus: Korzika, (7) ichnusae: Szardínia, (8) albipectus: Olaszország, (9) jordansi: Szicília, (10) graecus: Görögország, (11) 
cretorum: Kréta, (12) ferdinandi: K-DK-Románia, Bulgária, (13) glaszneri: Ciprus, (14) septentrionalis: KEurópa, (15) severtzowi: K-Európa. [Ezen alfajt GLUTZ (1993) a glandarius $\times$ brandti átmeneti, hibrid alakjaként nevezte meg.]

(B) Cervicalis-alfajcsoport: fejtetőjük egyöntetüen fekete, szárnytükrük egyszerű kék-fekete-fehér. KEVE (1995) a fekete fejü szajkók csoportjába sorolja alcsoportként. (16) whitakeri: É-Marokkó, ÉNy-Algéria, (17) cervicalis: É-Algéria és É-Tunézia, (18) minor: Középső- és Magas-Atlasz, Szaharai-Atlasz (Marokkó, Algéria).

(C) Atricapillus-alfajcsoport: fejtetőjük egyöntetűen fekete, szárnytükrük egyszerü kék-fekete-fehér. KEVE (1995) a fekete fejü szajkók csoportjába sorolja alcsoportként. Alfajai (KEVE, 1973b): (19) zervasi: Leszvosz, (20) samios: Számosz, (21) rhodius: Ródosz, (22) hansguentheri: Kisázsia Ny-i része, (23) anatoliae: Kisázsia középső és K-i része, (24) iphigenia: Krím-félsziget, (25) krynickii: É-Kaukázus, (26) caspius: Azerbajdzsán, (27) atricapillus: Libanon, Közel-Kelet, (28) hyrcanus: É-Irán, (29) susianae: Zagrosz-hg, Ny-Irán.

(D) Brandti-alfajcsoport: a fejtető vörös alapon feketével sávozott, szárnytükrük egyszerü kék-fekete-fehér. (30) brandti: a Pecsora vidékétől az Uralon át a Bajkálon túlig. (31) bambergi: É-Mongólia, (32) ussuriensis: az Usszúri vidéke, (33) okai: Közép-Korea, (34) kansuensis: Közép-Kína hegyvidéki erdei, (35) taczanowskii: Szahalin, (36) kurilensis: Kuril-szigetek, (37) pallidifrons: Hokkaido (japán).

(E) Japonicus-alfajcsoport: a fejtető fehér alapon feketén sávozott, csak egyszerü kék-fekete-fehér szárnytükrük van, kisebb testüek. (38) japonicus: Hondo (Japán), (39) tokugawae: Szado, (40) namiyei: Tsishima (Honshu), (41) hiugaensis: Kyushu, (42) orii: Yakushima.

(F) Bispecularisalfajcsoport: a fejtető rozsdás, sávozás nélküli, kettőzött kék-fekete-fehér szárnytükrük van. (43) bispecularis: Himalája, (44) interstinctus: Nepál, India (Darjeeling), (45) persaturatus: Assam, (47) asureitinctus: Manipur (India), (48) rufescens: Jünnan, D-Kína, (49) taivanus: Tajvan, (50) sinensis: Fucsien, DK-Kína, (51) rubrosus: Hanku, Pohaj-öböl, (52) minhoensis: Ny-Szecsuan, (53) pekingensis: Peking vidéke, (54) oatesi: Chin-hg, Burma (korábban önálló fajnak tartották), (55) haringtoni: Viktoria-hg, Burma (több szerző hibrid alfajnak tartja).

(G) Leucotis-alfajcsoport: a fejtető fekete, kettőzött kék-fekete-fehér szárnytükrük van. (56) leucotis: Hátsó-India (K-Burma, É-Thaiföld, Laosz, Vietnám).

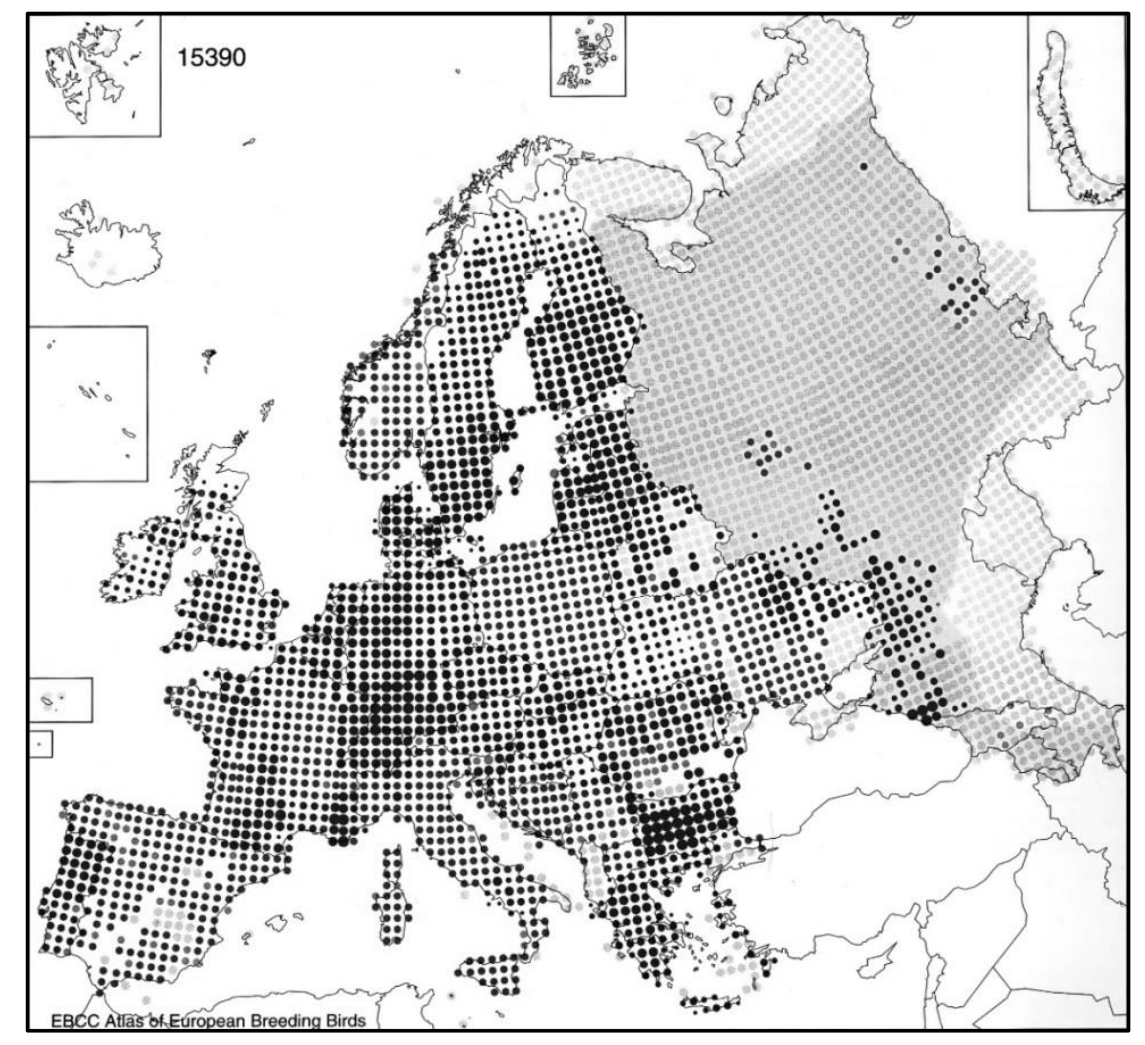

2. térkép: A szajkó elterjedése Európában (BEIĆEK \& GORBAN 1997)

Map 4: Distribution of Eurasian Jay in Europe (BEIĆEK \& GORBAN 1997) 
MADGE (2017) szerint a jelenlegi alfaji felosztás az alábbi:

G. g. hibernicus - Írország

G. g. rufitergum - Közép és Dél-Skócia, Anglia, Wales és ÉNy-Franciaország.

G. g. glandarius - É- \& Közép-Európa, keletre az Uraligs.

G. g. fasciatus - Spanyolország és Portugália.

G. g. corsicanus - Korzika.

G. g. ichnusae - Szardínia.

G. g. albipectus - Olaszország, Szicília és Dalmát tengerpart.

G. g. graecus - Ny-Balkán, beleértve Görögország szárazföldi területeit.

G. g. ferdinandi-K-Bulgária és a határos É-Trákia.

G. g. cretorum - Kréta.

G. g. glaszneri-Ciprus.

G. g. whitakeri- É-Marokkó és ÉNy-Algéria.

G. g. minor - Közép-Marokkó és Algéria Szakarai Atlasz területe.

G. g. cervicalis - É-ÉK Algéria és ÉNy Tunézia.

G. g. samios Keve-Kleiner, 1939 - Szamosz és Kos (Görögország), az Égei-tenger DK-i részén

G. g. anatoliae Seebohm, 1883 - W, C \& E Turkey E to N Iraq and W Iran.

G. g. iphigenia - Krím.

G. g. krynicki - Kakukázus \& ÉK Törökország.

G. g. atricapillus - Ny-Szíria, Ny-Jordánia and és Izrael határos része.

G. g. hyrcanus - D-Kaszpi erdők DK-Azerbajdzsánban és É-Iránban.

G. g. brandtii - D-Szibéria az Uraltól keletre Szahalinig, délen É-Mongóliáig, ÉNy \& ÉK Kínáig, Koreáig és É-Japánig (Hokkaido).

G. g. kansuensis - Közép-Kína (Qinghai, Gansu és ÉNy Szecsuán).

G. g. pekingensis - K-Kína (D-Liaoning, Peking, Shanxi, Hebei).

G. g. japonicus - Közép-Japán (Honshu és Oshima).

G. g. tokugawae - Sado I (Honshun kívül).

G. g. hiugaensis - Kyushu (Japán középső déli rész).

G. g. orii - Yakushima (D-Japán).

Számos további alfaját leírták (lásd GLUTZ 1993, KEVE 1995), amelyek a mai felfogás szerint átmeneti populációknak, vagy szinonimáknak tekinthetők. MADGE (2017) szerint az armoricanus és a caledoniensis benn foglaltatik rufitergum; a septentrionalis a törzsalakban; lusitanicus a fasciatus; a yugoslavicus és jordansi az albipectus; oenops és theresae a minor; a rhodius, a zervasi, a chiou, a susianae és a hansguentheri az anatoliae; a nigrifrons a krynicki; a caspius a hyrcanus; a sewerzowii, a bambergi, a pallidifrons, a kurilensis és az ussuriensis a brandtii; a diaphorus a pekingensis; a namiyei a japonicus; és a schimoizumii a hiugaensis alfajokban.

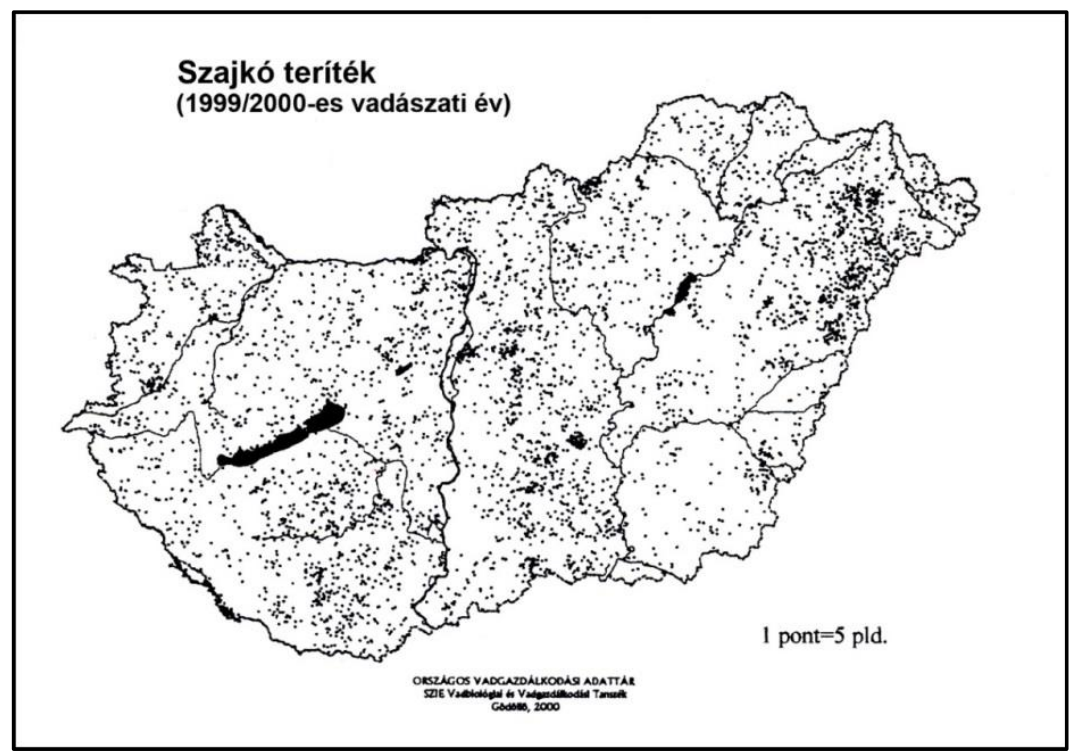

\section{3. térkép: A szajkó elterjedése Magyarországon az 1999/2000-es vadászati év terítéke alapján (OVA alapján)}

Map 3: Distribution of Eurasian Jay in Hungary on the basis of bag of the hunting season 1999/2000 (after NATIONAL GAME MANAGEMENT DATABASE) 
Hazánkban is, mint mindenütt a világon, erdős területeinken fordul elő (3-4. térkép). Fészkelő állományunkat a törzsalak - G. g. glandarius jelenti (KEVE 1995, MAGYAR et al. 1998), míg alkalmanként, olykor invázió keretében az itáliai alfaj, a G. g. albipectus is előfordul (27 bizonyított előfordulás) (KeVE KleINER 1942; KeVE 1967; MAGYAR et al. 1998).

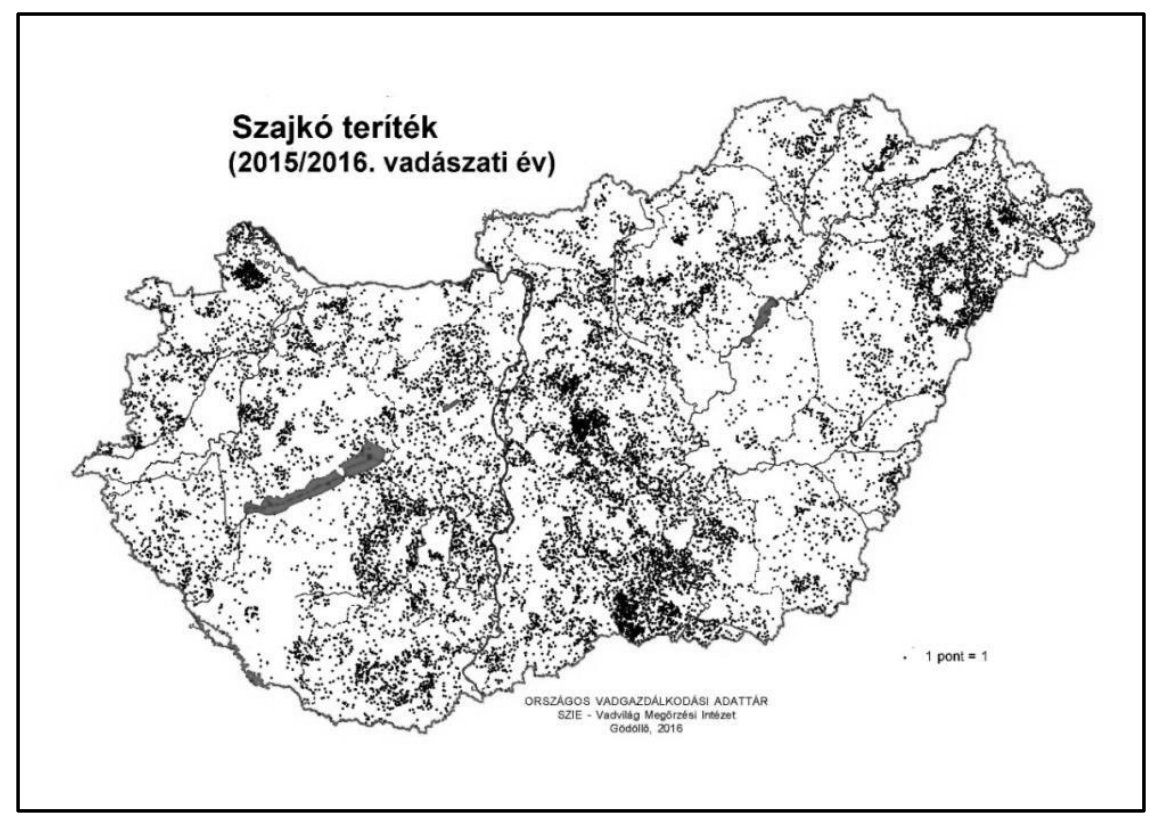

\section{4. térkép: A szajkó elterjedése Magyarországon a 2015/2016-os vadászati év terítéke alapján (OVA alapján)}

Map 4: Distribution of Eurasian Jay in Hungary on the basis of bag of the hunting season 2015/2016 (after NATIONAL GAME MANAGEMENT DATABASE)

\subsection{VÁNDORLÁS ÉS TELELÉS}

A szajkó állandó madár, kóborlása azonban általános jelenség. Rendszertelenül inváziói is megfigyelhetők, ezek a példányok vagy az északi/északkeleti populációból származnak (pl. Ukrajna), vagy olykor déli beáramlás is történhet. Utóbbi esetén jelenhetnek meg Magyarországon a G. g. albipectus példányai (KEVE 1967). Az inváziós jellegü megjelenés mellett rendszeres, bár nem szembetünő vonulása is ismert (VASVÁRI 1933). Két Kijev környéki madár 753 és $822 \mathrm{~km}$ megtétele után érkezett hozzánk, de ismert egy cseh madár magyar megkerülése is. Magyar szajkók Közép-Európában kóborolhatnak mind északra (Szlovákiáig - 2 megkerülés, $320 \mathrm{~km}$ ), mind délre (Horvátországig - 1 megkerülés, $278 \mathrm{~km}$ ). Ez a kóborlás olykor nagyobb csapatokban is történhet, mint azt MöDLINGER (1975) a Budapesti Állatkert fölött 1972. szeptember 25-én 07-09 óra között - DNy irányba, laza csapatokban átrepülő mintegy 800-900 szajkó esetében - megfigyelte. 2019/2020 telén az egész Nyugat-Dunántúlon jelentős észak-déli vonulását lehetett megfigyelni, heteken keresztül kisebb-nagyobb csapatokban. Emellett Magyarországon jelölt szajkóról érkezett visszajelentés Oroszországból, 2141 km távolságból (FARAGÓ 2001b; BANKOVICS \& VADÁSZ 2009) (5. térkép). 


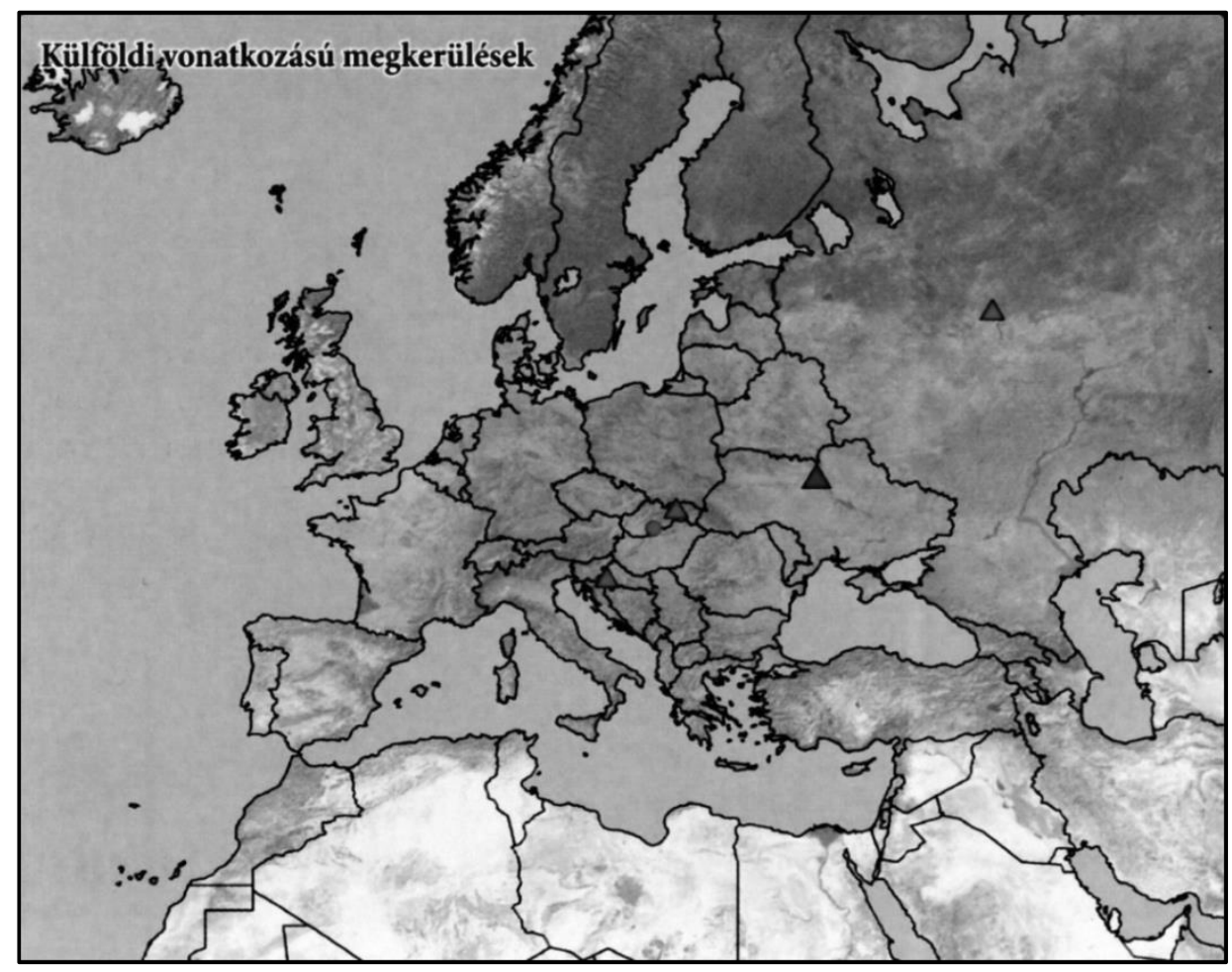

5. térkép: A szajkó külföldi vonatkozású megkerülései (BANKOVICS \& VADÁSz 2009)

Map 5: Recoveries of ringed Eurasian Jay in abroad (BANKOVICS \& VADÁSZ 2009)

\section{5. ÁlLOMÁNYNAGYSÁG}

A szajkó európai állományát az 1990-es években 5134 000-9 429000 pd, orosz állományá 1000 000-10 000000 pd, török állományát 100 000-1 000000 pd közötti értékkel határozták meg (BEJĆEK \& GORBAN 1997). A 2000-es évek elején az európai állomány 6000 000-13000 000 pár lehetett (BIRDLIFE INTERNATIONAL, 2004) (1. táblázat, 6. térkép).

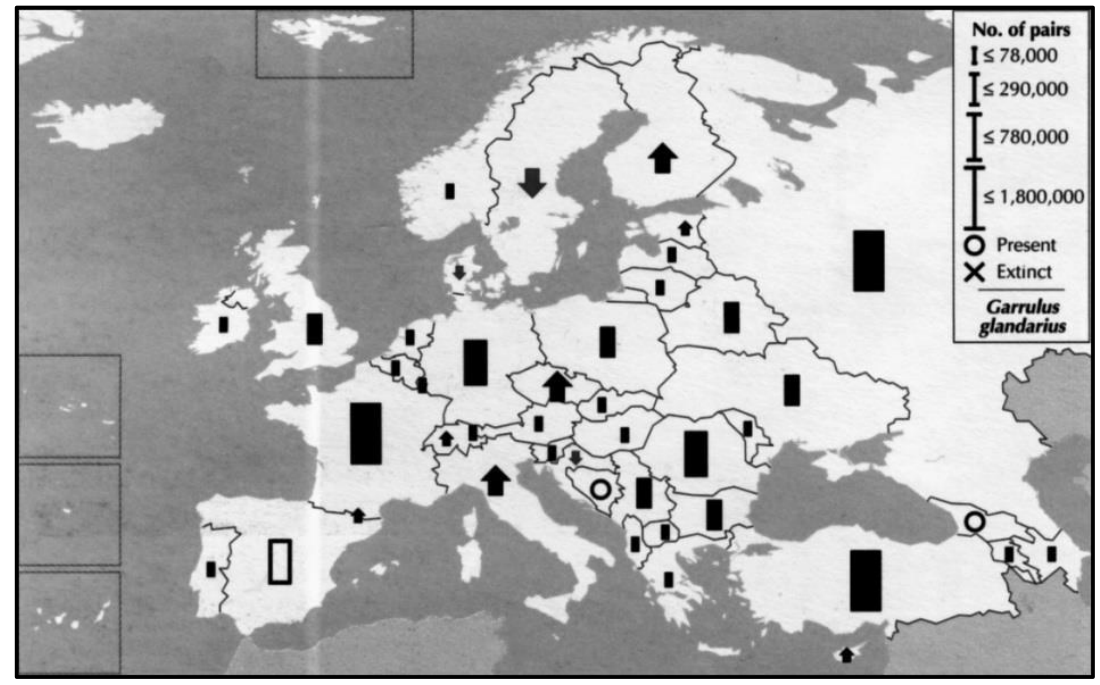

6. térkép: A szajkóállományok dinamikája Európa egyes országaiban (BIRDLIFE INTERNATIONAL, 2004)

Map 6: Trends of Eurasian Jay populations of different countries in Europe (BIRDLIFE INTERNATIONAL 2004) 
1. táblázat: A szajkó állományok nagysága Európa országaiban (BIRDLIFE INTERNATIONAL, 2004)

Table 1: Eurasian Jay populations in European countries (BIRDLIFE INTERNATIONAL, 2004)

\begin{tabular}{|c|c|c|c|c|}
\hline $\begin{array}{l}\text { Ország } \\
\text { Country }\end{array}$ & $\begin{array}{l}\text { Fészkelő állomány (pár } \\
\text { Breeding pop. size (pairs) }\end{array}$ & Év(ek) Year(s) & $\begin{array}{l}\text { Trend } \\
\text { Trend }\end{array}$ & $\begin{array}{l}\text { Növ. \% } \\
\text { Mag. \% }\end{array}$ \\
\hline Albania & $5.000-10.000$ & 02 & $(0)$ & $(0-19)$ \\
\hline Andorra & $(300-400)$ & $99-01$ & $(+)$ & $(20-29)$ \\
\hline Armenia & $3.000-5.000$ & $00-02$ & 0 & $0-19$ \\
\hline Austria & $(20.000-40.000)$ & $98-02$ & $(0)$ & $(0-19)$ \\
\hline Azerbaijan & $(10.000-50.000)$ & $96-00$ & (0) & $(0-19)$ \\
\hline Belarus & $220.000-250.000$ & $97-02$ & $(0)$ & $(0-19)$ \\
\hline Belgium & $30.000-40.000$ & $01-02$ & 0 & $0-19$ \\
\hline Bosnia \&HG & Jelen/Present & $90-03$ & $?$ & - \\
\hline Bulgaria & $100.000-400.000$ & $96-02$ & 0 & $0-9$ \\
\hline Croatia & $(50.000-100.000)$ & 02 & $(-)$ & $(30-49)$ \\
\hline Cyprus & $(5.000-10.000)$ & $94-02$ & $(+)$ & $(0-9)$ \\
\hline Czech Rep. & $170.000-340.000$ & 00 & + & $0-19$ \\
\hline Denmark & $30.000-50.000$ & 00 & - & 30 \\
\hline Estonia & $(20.000-40.000)$ & 98 & + & $20-29$ \\
\hline Finland & $150.000-200.000$ & $98-02$ & + & 20 \\
\hline France & $(500.000-2.000 .000)$ & $98-02$ & $(\mathrm{~F})$ & $(20-29)$ \\
\hline Georgia & Jelen/Present & 03 & $?$ & - \\
\hline Germany & $300.000-760.000$ & $95-99$ & 0 & $0-19$ \\
\hline Greece & $(20.000-50.000)$ & $95-00$ & $(0)$ & $(0-19)$ \\
\hline Hungary & $58.000-81.000$ & $99-02$ & 0 & $0-19$ \\
\hline Rep. Ireland & $2.500-10.000$ & $88-91$ & 0 & $0-19$ \\
\hline Italy & $(200.000-400.000)$ & 03 & $(+)$ & $(0-19)$ \\
\hline Latvia & $20.000-40.000$ & $90-00$ & $(0)$ & $(0-19)$ \\
\hline Liechtenstein & $150-200$ & $98-00$ & $(0)$ & $(0-19)$ \\
\hline Lithuania & $(60.000-100.000)$ & $99-01$ & $(0)$ & $(0-19)$ \\
\hline Luxembourg & $3.000-4.000$ & 02 & 0 & $0-19$ \\
\hline Macedonia & $(40.000-80.000)$ & $90-00$ & $(0)$ & $(0-19)$ \\
\hline Moldova & $15.000-20.000$ & $90-00$ & 0 & $0-19$ \\
\hline Netherlands & $40.000-60.000$ & $98-00$ & 0 & 10 \\
\hline Norway & $(10.000-100.000)$ & $90-03$ & $(0)$ & $(0-19)$ \\
\hline Poland & $200.000-400.000$ & $00-02$ & 0 & $0-19$ \\
\hline Portugal & $(10.000-100.000)$ & 02 & $(0)$ & $(0-19)$ \\
\hline Romania & $(460.000-580.000)$ & $00-02$ & $(0)$ & $(0-19)$ \\
\hline Russia & $1.200 .000-2.500 .000$ & $90-00$ & $(0)$ & $(0-19)$ \\
\hline Serbia \&MN & $200.000-300.000$ & $90-02$ & 0 & $0-19$ \\
\hline Slovakia & $15.000-30.000$ & $90-99$ & 0 & $0-19$ \\
\hline Slovenia & $10.000-20.000$ & 00 & $(0)$ & $(0-19)$ \\
\hline Spain & $(540.000-1.100 .000)$ & 92 & $?$ & - \\
\hline Sweden & $200.000-400.000$ & $99-00$ & - & 10 \\
\hline Switzerland & $50.000-70.000$ & $93-96$ & + & $0-9$ \\
\hline Turkey & $(600.000-1.800 .000)$ & 01 & $(0)$ & $(0-19)$ \\
\hline Ukraine & $225.000-320.000$ & $90-00$ & 0 & $0-19$ \\
\hline UK & $160.000-160.000$ & 00 & 0 & 0 \\
\hline Összes - Total & $6.000 .000-13.000 .000$ & \multicolumn{2}{|c|}{ Trend: stabil Stable } & $\begin{array}{l}\text { Világállomány } \\
25-49 \%\end{array}$ \\
\hline
\end{tabular}

Becslések szerint Magyarország fészkelő szajkóállománya 1992-ben meghaladhatta a 150000 párt. MAGYAR et al. (1998) szerint az 1990-es évek második felében 60 000-100 000 
pár szajkó fészkelt hazánkban. A 2000-es évek első évtizedében végzett becslés szerint 58 000-81 000 pár költött Magyarországon (MME NOMENCLATOR BizOTTSÁG, 2008).

A hazai állomány változásáról a fészkelési és a telelési időszakra vonatkozóan a Mindennapi Madaraink Monitoring (MMM) program szolgál információkkal (1-2. ábra) (MME 2017).

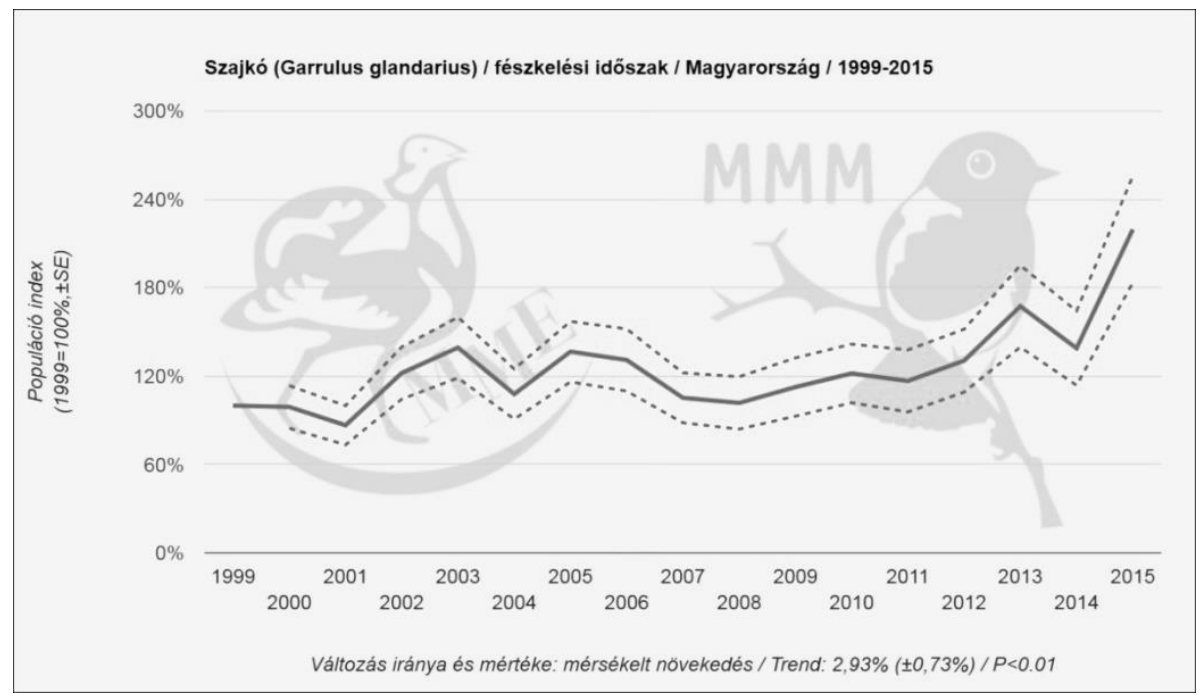

\section{1. ábra: A szajkóállomány alakulása Magyarországon az MMM fészkelési időszakbeli adatai alapján (MME 2017)}

Figure 1: Dynamics of the Eurasian Jay in Hungary, on the base of the date of MMM in the breeding season (MME 2020)

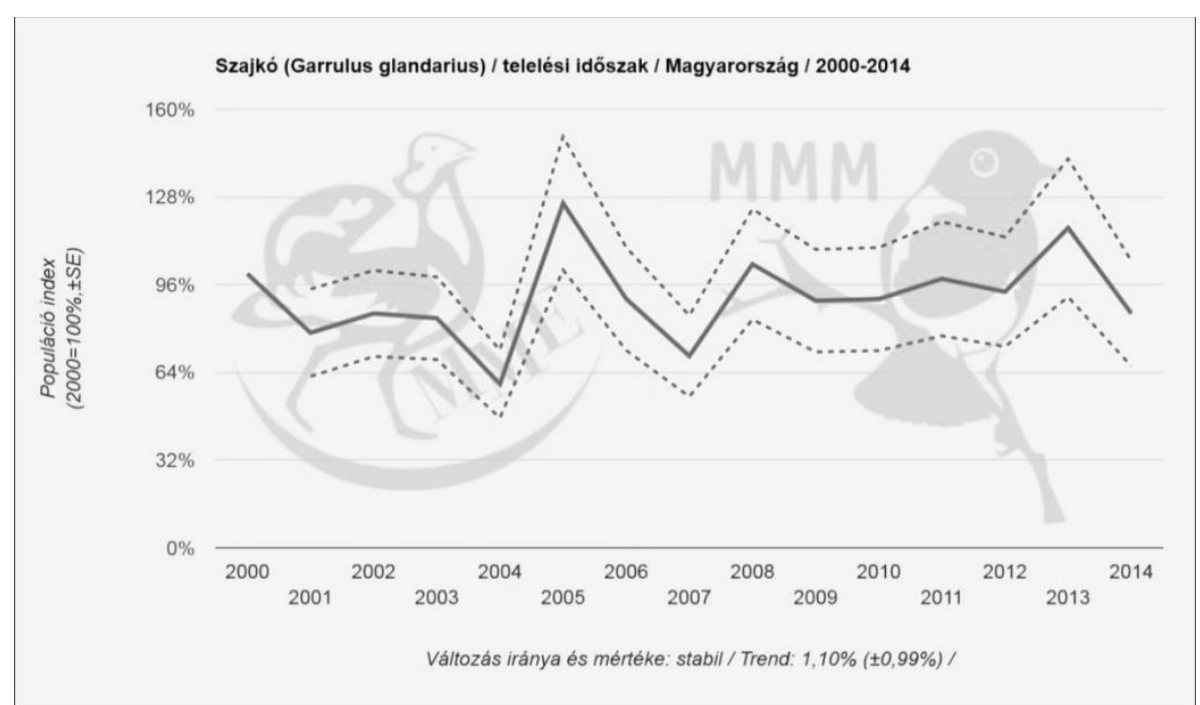

2. ábra: A szajkóállomány alakulása Magyarországon az MMM telelési időszakbeli adatai alapján (MME 2017)

Figure 2: Dynamics of the Eurasian Jay in Hungary, on the base of the date of MMM in the wintering season (MME 2020)

Az elmúlt 30 évben 22 000-35 000 pd között változott éves terítéke. Talán az 1970-es évek végén, az 1980-as évek elején volt magasabb a teríték az átlagnál. Erre az időre esik az ország egyes területein kimutatható szajkóállomány növekedés, így pl. VARGA (1984) a Zagyva forrásvidékén, SCHMIDT (1989) a Gellért-hegyen mutatott ki ilyen folyamatot. 
Az eredmények a fészkelési időszakban jelentős állománynövekedést, a telelési időszakban hullámzó dinamika mellett állandóságot mutatnak 1999-2015 időszakára.

\subsection{TERMÉSZETES KORLÁTOZÓ TÉNYEZÖK}

\subsubsection{A populáció sürüségét befolyásoló elsődleges paraméterek}

A természetes populációsürüséget a termékenység, a halandóság illetőleg a be-és elvándorlás határozza meg a szarka esetében is. A vadgazda feladata, amely megerösítést nyer a természetvédelmi szabályozási szükséglet által - mivel dúvad fajról van szó -, hogy a termékenység növekedését elősegítő faktorokat gyengítse, a halandóságot növelőket pedig a faj megtartása mellett erősítse. Az állománynövelő bevándorlást szabályozott keretek között folytatott dúvadgazdálkodás segítségével lehet kontrollálni.

A termékenységet szajkó esetében

(1) a táplálékforrás (állati, növényi) mennyisége és minősége, illetőleg

(2) a fészkelöhelyek hiánya korlátozza.

Az ezzel összefüggő halandóságot

(1) a táplálékforrás mennyisége és minősége, valamint

(2) a dúvadszabályozás határozzák meg.

\subsubsection{A populáció sürüségét befolyásoló környezeti tényezők}

A szajkó - mint azt az 1.2.1. fejezetben láttuk - síksági, domb- és hegyvidéki lomberdők, elegyes állományok lakója. Kedveli, és előnyben részesíti a tölgyeseket, csereseket és bükkösöket, vagy e fafajokkal elegyes erdőket. Olykor fenyvesekben is elöfordul. Megtelepszik ártéri és galériaerdőkben, arborétumokban, városszéli parkokban is. Vonulása, vagy rövidtávú migrációja során megjelenhet a fenti tipikus területektől eltérő élöhelyeken, így pl. az erdősávokban is. Hazai elterjedése - amelyet terítékének megoszlásával (3-4. térkép) igazolhatunk, az erdőterületek, pontosabban a fás vegetáció jelenlétéhez köthető, ezért az ország egész területén előfordul. alábbiak:

A szajkó fészkelőhely (általában élőhely) választásának ökológiai motivációi az

1. Az élettér szerkezete a keményfás makktermö, fenyővel mozaikosan létrejött erdőszerkezet, valamint a vonulást, migrációt segítő, zöldfolyosó funkciójú erdősávok, egész évben biztosítja a szajkó életfeltételeit.

2. A legfontosabb a szajkó fészkelésére alkalmas erdei/fás élőhelyek állományainak vertikális szerkezete megfelelö fészkelő helyet biztosít.

3. Az erdei élőhelyek, a fészkelés és a fiókanevelés során megfelelő mennyiségben és minőségben kínálják az állati eredetü táplálékot (lásd 1.2.3. fejezet)

4. Az eltérő korú, szerkezetü, elegyarányú faállományok táplálékkínálata részben kiegészíti, részben helyettesíti az időben átalakuló táplálékforrást, így a teljes vegetációs időszak kielégíti mind a felnőtt madarak, mind a fiókák állati eredetű táplálék szükségletét.

5. Kiemelkedő fontosságú a makktermü állományok szerepe. 


\subsubsection{A vadászat hatása}

A szajkó terítéke - bizonyosan nagyobb állománynagyság mellett - az 1970-es évek elején 17409 példányról 1972-re 24937 példányra nőtt. Ezt követően - évenkénti hullámzással - 1982-ben érte el félévszázados maximumát 30999 példánnyal. A tetőzés után egészen 2010-ig - ugyancsak hullámzó módon - folyamatosan csökkent a statisztikákban kimutatott éves lelőtt mennyisége. 2010-ben mindössze 13239 példányt jelentettek a statisztikákban.

A csökkenést mindenekelőtt az érdektelenség (azaz nem elsősorban vadgazdálkodási célból van a vadászható fajok listáján a faj) határozza meg, a hullámzás pedig a táplálékkínálat (makk) változása okozza.

Az 1970-es évek második felében kezdték kiterjedten használni a 3-kloro-4metilanilin-hidroklorid hatóanyaggal preparált ú.n. F-2-es tojásokat, amelyek a varjúfélékre szuperszelektív hatással bírva gyérítették az állományokat. A szer erdei használata nem terjedt el, így azt a szajkószabályozásra alig használták, bár a mezei területekre kijáró szajkók e preparált tojásokat felvehették, s valószínüleg fel is vették. Hagyományos fegyveres gyérítéssel csak csökkenő mennyiségben lehetett terítékre hozni.

Az igazsághoz az is hozzátartozik, hogy a rendszerváltoztatás után az új vadászterületeken a vadgazdálkodás, benne a dúvadszabályozás hatékonysága meg sem közelítette az 1970-es évek gyakorlatát.

A szajkó terítéke az 1990-es évektől visszaesést mutatott, az alábbi értékekkel, 1995: 24384 pd, 2000: 20823 pd, 2005: 16020 pd, 2010: 13239 pd, 2011: 15319 pd, 2012: 15968 pd, 2013: 15303 pd, 2014: 19145 pd, 2015: 16855 pd (CSÁNYI, 1999, 2001; CSÁNYI et al., 2005; 2010; 2012a; 2012b; 2014; 2015; 2016) (1. ábra), amelynek megyei szintü megoszlását a 2. táblázat mutatja.

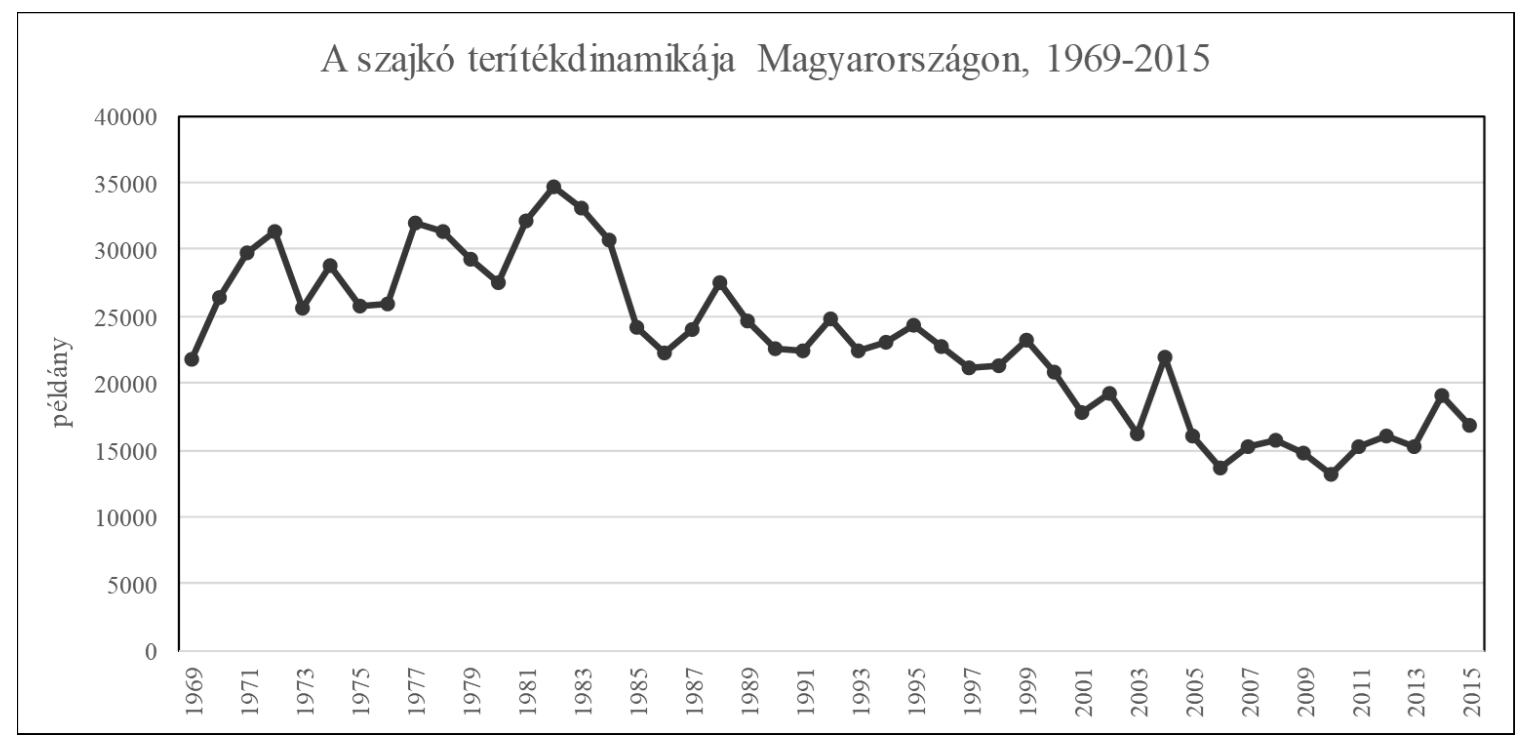

1. ábra: A szajkó teríték alakulása 1969-2015 között Magyarországon (OVA alapján)

Figure 1: Eurasian Jay bags between 1969 and 2015 in Hungary (based on the NATIONAL GAME MANAGEMENT DATABASE) 


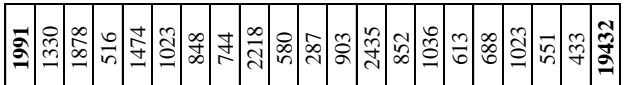

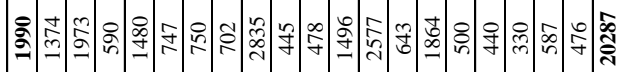

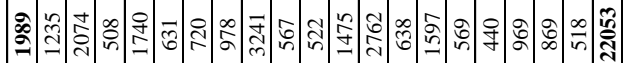

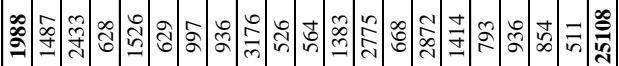

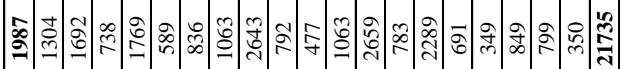

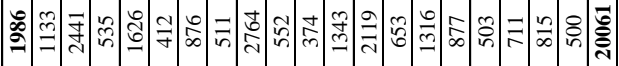

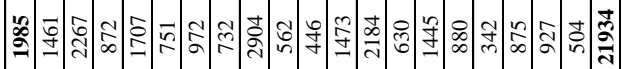

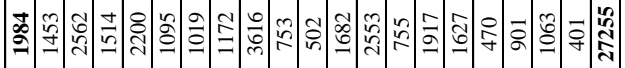

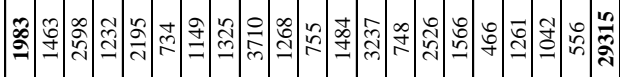

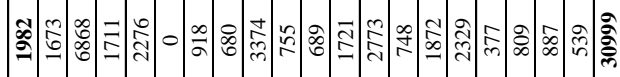

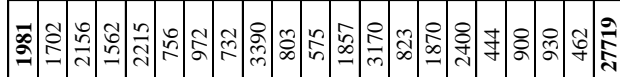

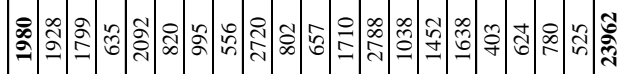

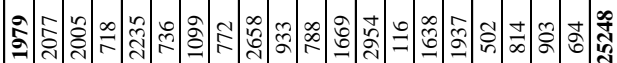

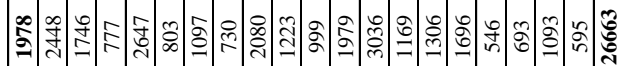

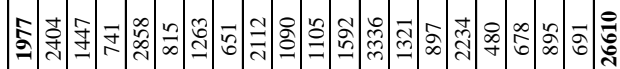

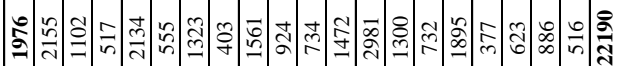

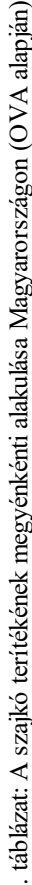

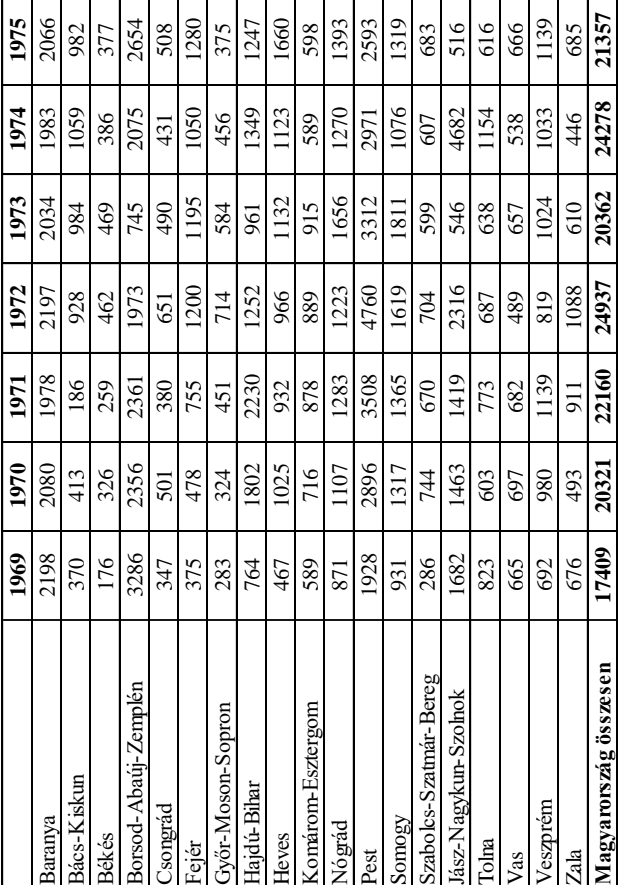

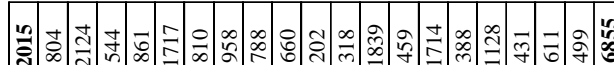

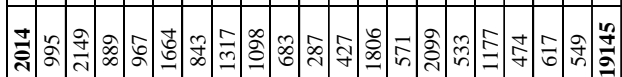

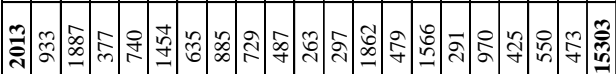

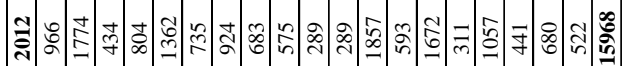

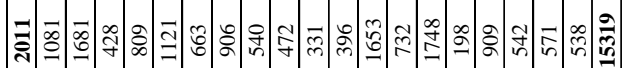

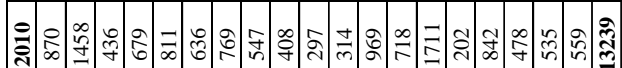

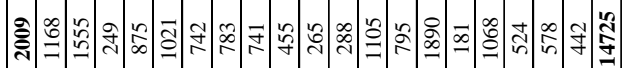

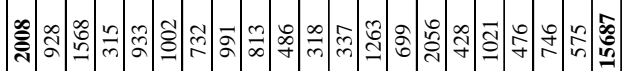

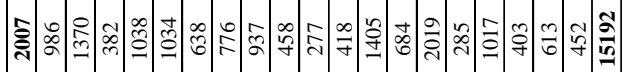

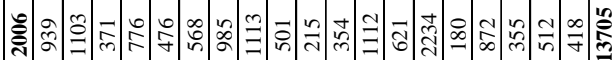

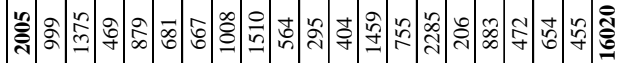

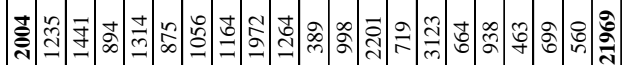

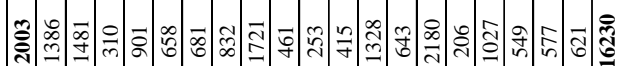

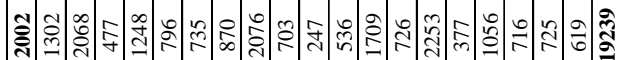

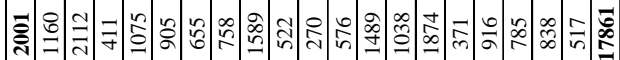

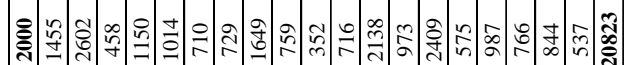

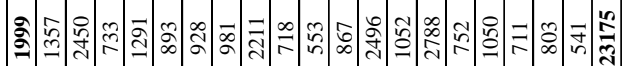

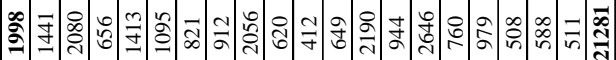

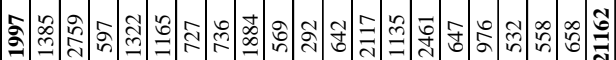

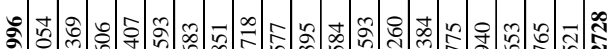

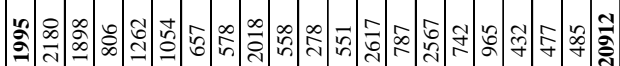

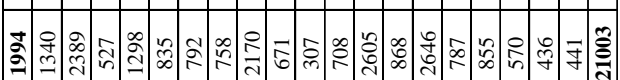

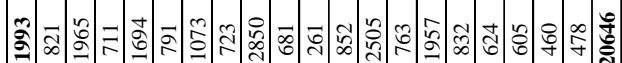

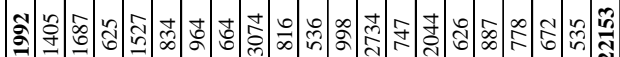

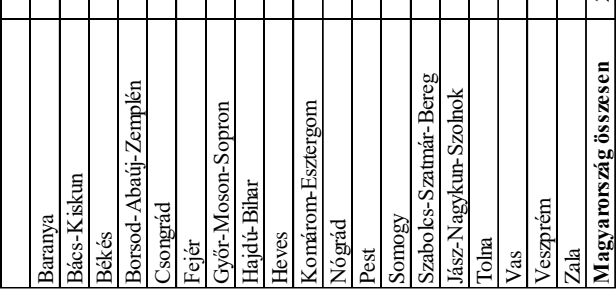




\subsubsection{A szajkóállományt szabályozó tényezők összefoglalása}

A szajkóállományt - mint láttuk - a fészkelőhelyek megléte, vagy hiánya, a táplálék mennyisége, a betelepülések mértéke és a vadászati szabályozás hatékonysága befolyásolhatják.

Paradoxon, hogy mindazon a fás formációk, amelyek kedvezöek a madárfajok (benne a vadászható fácán és a fogoly) megtartása, védelme szempontjából, fészkelöhelyet biztositanak fészek-predátoraiknak, köztük a szajkónak is. A szajkó állati és növényi eredetü táplálékforrása ugyanolyan mértékben biztositott, mint valamennyi madárfaj esetében.

$\mathrm{Az}$ erdei és mezei élöhely-védelem és élöhely fejlesztés - a bölcs hasznosítás folyományaként - a fészkelöhely és táplálékforrás biztosítása révén, egyúttal a szajkópopuláció megsegítését is jelenti. Éppen ezért bárminemü madárfaj védelmének semmivel sem helyettesíthetö, része a dúvad-gazdálkodás, benne a szajkó állomány szabályozása.

\subsection{A VADÁSZATI SZABÁLYOZÁSI GYAKORLAT KRITIKAI ÉRTÉKELÉSE}

A szajkó korábban egész évben vadászható volt Magyarországon, amit az EU madárvédelmi irányelv - fészkelő populáció védelme - alapján július 1. - február 28(29). közti időszakra kellett módosítani. E változás következményei kedvezötlenek lennének mind a vadgazdálkodás, mind a természetvédelem számára - a faj madárfészekben okozott kártétele miatt -, de a vadászati rendelet, apróvadas vadászterületeken, az apróvad szaporodási időszakában, a vadászati hatóság külön engedélyéhez kötve lehetővé teszi gyérítését.

Állományszabályozását télen is lehet végezni, amit megenged a február 28(29)-ig tartó vadászati idénye.

A szaporodási időszakban végzendő, tulajdonképpen fészkelő-állomány szabályozás alapfeltétele a fészkek helyének megközelítő ismerete. Ez a vadászterületeken sem vad-, sem természetvédelmi alapon nem gyakorlat. Ennek ismeretében lehet fegyveres szabályozást, akár csapdázást elvégezni. Tavasszal - a fészkek környékén - elsősorban a LARSEN-csapda különböző változatainak, valamint a TROLLE-LJUNGBY L84 csapdának a használata eredményes (HAJAS, 2007; 2011; 2012) - ezért kell ismerni a lakott fészkek helyét.

Minden csapdatípus sikeres almazásának a kulcsa - a vonatkozó szabályok betartása mellett - az élő csaliállat használata. TAPPER et al. (1991) felmérése szerint a LARSEN-csapdák élő csalival 10-15-ször hatékonyabbak. (A csalimadarak következő szezonra történő eltárolásával és átteleltetésével szemben, jóval költségkímélőbb és egyszerübb alternatíva az új szezon elején, jól álcázható csapóhálók használatával új csalimadarak befogása). 
3. táblázat: A szajkó (Garrulus glandarius) teríték dinamikája a LAJTA Projectben (1992-2016)

Table 3: Bag dynamics of Eurasian Jay in the LAJTA Project (1992-2016)

\begin{tabular}{|l|c|c|c|c|c|c|c|c|c|c|c|c|c|}
\hline & Jan. & Feb. & Már. & Ápr. & Máj. & Jún. & Júl. & Aug. & Szept. & Okt. & Nov. & Dec. & Összeg \\
\hline $\mathbf{1 9 9 2}$ & 0 & 0 & 0 & 1 & 0 & 0 & 0 & 0 & 0 & 0 & 0 & 0 & $\mathbf{1}$ \\
\hline $\mathbf{1 9 9 3}$ & 0 & 0 & 0 & 0 & 0 & 0 & 0 & 0 & 0 & 0 & 0 & 0 & $\mathbf{0}$ \\
\hline $\mathbf{1 9 9 4}$ & 0 & 0 & 0 & 0 & 0 & 0 & 0 & 0 & 0 & 0 & 0 & 0 & $\mathbf{0}$ \\
\hline $\mathbf{1 9 9 5}$ & 0 & 0 & 0 & 0 & 0 & 0 & 0 & 0 & 0 & 0 & 0 & 0 & $\mathbf{0}$ \\
\hline $\mathbf{1 9 9 6}$ & 0 & 0 & 0 & 0 & 0 & 0 & 0 & 0 & 0 & 0 & 1 & 0 & $\mathbf{1}$ \\
\hline $\mathbf{1 9 9 7}$ & 0 & 0 & 2 & 0 & 0 & 0 & 0 & 0 & 0 & 0 & 0 & 0 & $\mathbf{2}$ \\
\hline $\mathbf{1 9 9 8}$ & 2 & 0 & 0 & 0 & 0 & 0 & 0 & 2 & 2 & 0 & 3 & 5 & $\mathbf{1 4}$ \\
\hline $\mathbf{1 9 9 9}$ & 0 & 0 & 0 & 0 & 0 & 0 & 0 & 0 & 2 & 0 & 0 & 0 & $\mathbf{2}$ \\
\hline $\mathbf{2 0 0 0}$ & 0 & 3 & 0 & 0 & 0 & 0 & 0 & 1 & 1 & 0 & 0 & 0 & $\mathbf{5}$ \\
\hline $\mathbf{2 0 0 1}$ & 0 & 0 & 0 & 0 & 0 & 0 & 0 & 0 & 0 & 0 & 2 & 0 & $\mathbf{2}$ \\
\hline $\mathbf{2 0 0 2}$ & 0 & 0 & 2 & 0 & 0 & 0 & 0 & 3 & 16 & 11 & 6 & 0 & $\mathbf{3 8}$ \\
\hline $\mathbf{2 0 0 3}$ & 0 & 0 & 0 & 0 & 0 & 0 & 0 & 0 & 0 & 0 & 5 & 0 & $\mathbf{5}$ \\
\hline $\mathbf{2 0 0 4}$ & 0 & 2 & 0 & 0 & 0 & 0 & 0 & 2 & 1 & 10 & 7 & 5 & $\mathbf{2 7}$ \\
\hline $\mathbf{2 0 0 5}$ & 2 & 0 & 0 & 2 & 2 & 2 & 0 & 2 & 6 & 7 & 4 & 5 & $\mathbf{3 2}$ \\
\hline $\mathbf{2 0 0 6}$ & 0 & 0 & 0 & 0 & 0 & 0 & 0 & 0 & 3 & 8 & 4 & 1 & $\mathbf{1 6}$ \\
\hline $\mathbf{2 0 0 7}$ & 4 & 9 & 0 & 0 & 0 & 0 & 0 & 7 & 6 & 11 & 6 & 3 & $\mathbf{4 6}$ \\
\hline $\mathbf{2 0 0 8}$ & 4 & 5 & 0 & 0 & 0 & 0 & 0 & 4 & 10 & 7 & 8 & 6 & $\mathbf{4 4}$ \\
\hline $\mathbf{2 0 0 9}$ & 5 & 8 & 2 & 0 & 0 & 2 & 5 & 10 & 6 & 3 & 7 & 5 & $\mathbf{5 3}$ \\
\hline $\mathbf{2 0 1 0}$ & 5 & 10 & 3 & 2 & 0 & 0 & 4 & 4 & 7 & 10 & 9 & 15 & $\mathbf{6 9}$ \\
\hline $\mathbf{2 0 1 1}$ & 2 & 5 & 0 & 0 & 0 & 0 & 0 & 6 & 8 & 7 & 8 & 16 & $\mathbf{5 2}$ \\
\hline $\mathbf{2 0 1 2}$ & 2 & 4 & 0 & 0 & 0 & 0 & 0 & 0 & 10 & 13 & 7 & 7 & $\mathbf{4 3}$ \\
\hline $\mathbf{2 0 1 3}$ & 8 & 2 & 2 & 2 & 0 & 0 & 6 & 4 & 4 & 5 & 6 & 7 & $\mathbf{4 6}$ \\
\hline $\mathbf{2 0 1 4}$ & 13 & 11 & 0 & 2 & 3 & 3 & 7 & 7 & 11 & 23 & 10 & 16 & $\mathbf{1 0 6}$ \\
\hline $\mathbf{2 0 1 5}$ & 4 & 0 & 0 & 0 & 0 & 0 & 0 & 0 & 0 & 3 & 5 & 3 & $\mathbf{1 5}$ \\
\hline $\mathbf{2 0 1 6}$ & 0 & 0 & 0 & 0 & 0 & 0 & 0 & 2 & 0 & 0 & 3 & 5 & $\mathbf{1 0}$ \\
\hline $\mathbf{A} t \mathbf{n g}$ & $\mathbf{2 , 0}$ & $\mathbf{2 , 4}$ & $\mathbf{0 , 4}$ & $\mathbf{0 , 4}$ & $\mathbf{0 , 2}$ & $\mathbf{0 , 3}$ & $\mathbf{0 , 9}$ & $\mathbf{2 , 2}$ & $\mathbf{3 , 7}$ & $\mathbf{4 , 7}$ & $\mathbf{4 , 0}$ & $\mathbf{4 , 0}$ & $\mathbf{2 5 , 2}$ \\
\hline
\end{tabular}

A hivatásos vadászok rendszeres területellenőrzéseik során bármikor elejthetik a szajkót. A LAJTA Projectben (3060 ha) csaknem negyed század alatt elejtett szajkók havi átlagos dinamikája szerint (3. táblázat; 2. ábra) az őszi-téli (augusztus-február) időszakban, tehát vonulása, illetve téli migrációja idején lötték a legtöbb példányt (FARAGÓ et al., 2012).

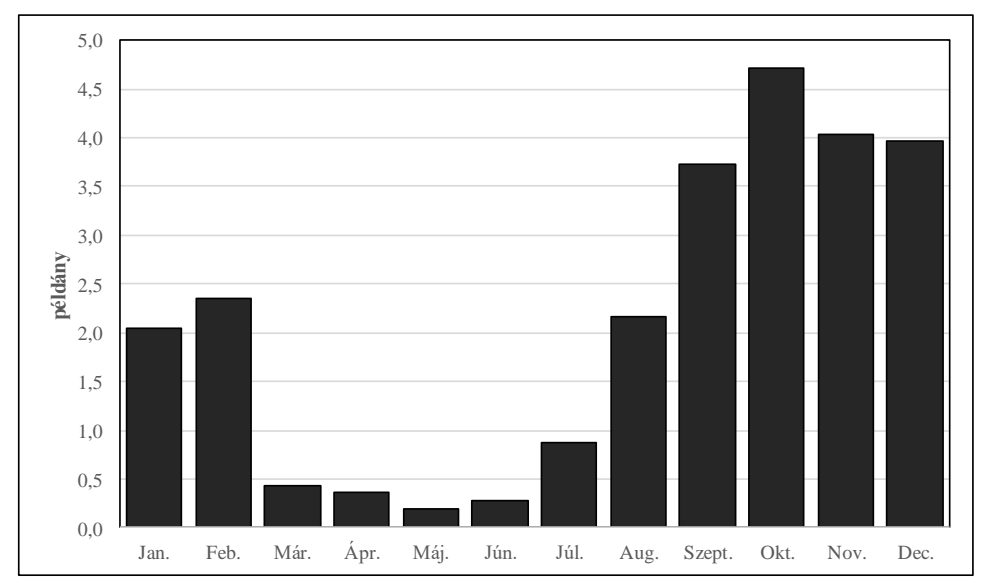

2. ábra: A szajkóteríték havi megoszlása a LAJTA Projectben

Figure 2: Monthly dynamics of Eurasian Jay in the LAJTA Project 


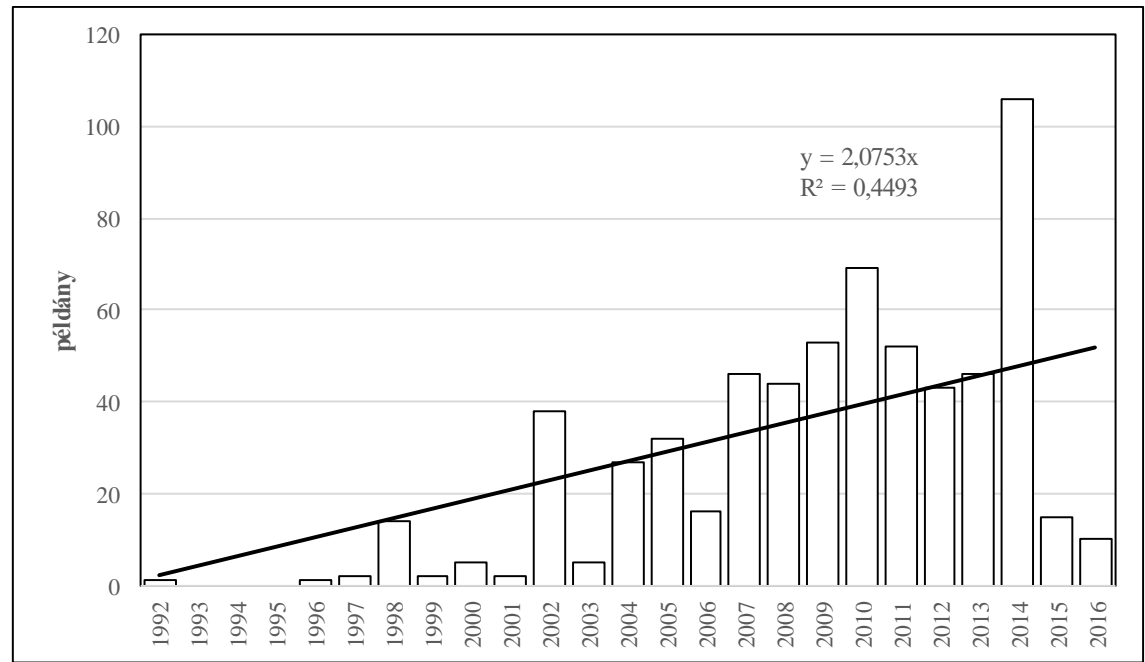

3. ábra: A szajkóteríték negyedszázados dinamikája a LAJTA Projectben Figure 3: Quarter-century dynamics of Eurasian Jay bag in the LAJTA Project

A tartamos szabályozás egy vadászterületen azonban ökológiai vákuumot okoz, azaz a szomszédos területekről egyre több példány települ be (3. ábra), ami a regionális szabályozás összehangolását kívánja, sőt kényszerítik ki, egyszersmind hozzájárul a fészkelö állományok szabályozásához.

\subsection{A SZAJKÓ GAZDASÁGI JELENTŐSÉGE}

Mindez ideig a szajkó erdei, mezei, gyümölcsösbeli és természetvédelmi „kártételét” hangsúlyoztuk a szakirodalom, s saját megfigyelések alapján.

A sZajkó erdészeti vonatkozású kedvező tevékenységét SZEKRÉNYES (2013) alapján foglaljuk össze.

Ellentétben a hasonló táplálékforrásokon élő mókusokkal, a szajkó nem halmoz fel nagyobb készleteket egy helyen, hanem egyesével rejti el a makkokat, így annak a veszélye, hogy más is megtalálja a forrást, sokkal kisebb. A korábbi elképzelések szerint a madár elfelejti, hogy az elrejtett makkot hova helyezte, de e helyett inkább szándékos tevékenységről van szó, ugyanis a fiókanevelési időszakban igen fontos a tölgysziklevéllel történő etetés. E periódusban egyébként ez már nem káros a fejlődő tölgycsemetékre nézve.

A szajkó kizárólag megfelelő súlyú, alakú, formájú és egészségi állapotú makkot vesz fel, utóbbit kopogtatással állapítja meg. Kedveli a nehezebb 4-5 g-os, hosszúkás kocsányos tölgy makkot. A kedveltség szerinti sorrend a következö: kocsányos tölgy, kocsánytalan tölgy, cser, vörös tölgy, mogyoró, bükkmakk.

A tölgyek dél-európai refúgiumokból való visszatelepülésében központi szerepet játszottak a szajkók. A terjedés sebessége $7 \mathrm{~km} / \mathrm{év}$ lehetett. Egyes szerzők szerint a madár 1$10 \mathrm{~km}$-es távolságba is szállíthatja a makkot. A terjedés sebességét jelentősen befolyásolja a nagy vaddisznósürüség. A gyors terjedésre jó példa az 1848-as forradalom után Poroszországban, vagy a 1945 után a szovjet megszállás idején, amikor a vaddisznó vadászat korlátozás nélkül történt, a fenyvesek (Pinus spp.) alatt jelentős tölgy újulat jelent meg. Utóbbit „orosztölgyeseknek” is hívták. HARTIG szerint a szajkó olyan szorgalmasan telepíti az értékes lombos fafajokat, hogy sok helyen csupán a tülevelüek kivágásával megoldható a lombosok felújítása.

A makk ültetése szeptembertől január elejéig tart, kivéve az extrém időjárási körülményeket. A szállított makk mennyisége a távolságtól függ, 100 m-ig egyesével történik. Ennél távolabbra több makk kerül a begybe, egyszerre akár 5-6 is, illetve a legnehezebb a 
csőrben szállítódik. GRÉDICS SzILÁRD okleveles erdőmérnök (szem. közl.) szilvásváradi tapasztalata szerint egy elejtett madár begyében $12 \mathrm{db}$ makk volt megtalálható. Az ültetést a csőrével végzi, egyszerüen a talajba nyomja a makkot, vagy keményebb talaj esetén kis gödröt kapar a csőrével. A takarás vastagsága ritkán nagyobb, mint a makk vastagsága. A takarást avarral, mohával, humuszos laza talajjal végzi, úgy hogy a csírázást ne gátolja, de a vízvesztést csökkentse. A madár gyakorta választja a makk rejtekhelyének a fák gyökérterpeszeinek védett, jó mikroklímájú hajlatát. Az egyes rejtekhelyek közötti távolság 0,15-15 m között változhat. Gyakori a magoncok egymástól 20-30 cm-re történő csoportos megjelenése is. Megfigyelések alapján egy szajkó 4600 makkot is elrejtett a tél beálltáig, VARGA BÉLA erdőmérnök (szem. közl.) 40000 darabban állapította meg a szajkó egy szezonbéli teljesítményét.

A szajkó megfelelő szubsztrátumba helyezi el a makkot, a vizsgálatok alapján a nyílt területeket (pl. katonai gyakorlótér nyílt területei erdős környezetben) nem preferálja. Fontos a madár számára a lágyszárú vegetáció borításának mértéke is. Fenyvesek alatt kedveli a moha borítású (1-20\%) területeket. Hasonlóan előnyösek a 10-70\% borítású a fekete áfonyás erdők. Az erdei sédbúza estében $20 \%$-os borításnál a legtöbb a magoncok száma, a kevésbé jó vízellátottságú területeken a nagyobb borítás érték túlzott konkurenciát jelent a magoncoknak. Összességében megállapítható, hogy a $20 \mathrm{~cm}$ alatti lágyszárú növényzet az ideális.

Erdőmüvelési szempontból olyan helyen használható ki a szajkó tevékenysége, ahol kellő mennyiségü termö tölgy van a területen, illetve a célnak megfelelö vadlétszám.

Összefoglalva a szajkó tevékenysége igen jól hasznosítható fenyvesek szerkezetátalakításában a fentiek figyelembe vételével.

2002. szeptember 13-án Németországban, a brandenburgi székes káptalan erdészeti hivatala által szervezett rendezvényen köszönetet mondtak és méltatták a szajkót, mint tiszteletbeli „fóerdészt”, s emlékkövet avattak tiszteletére (LOBODA 2002).

Magyarországon a Balaton-felvidéki pusztuló feketefenyvesek lombos erdővé történő természetes átalakulásában vizsgálta a szajkó (Garrulus glandarius) szerepét SzEKRÉNYES (2013). Megállapította, hogy a szajkó elvitathatatlan szerepe miatt érdemes átgondolni jelentöségét és értékelését. Megfontolás tárgyát képezhetné, hogy a megyei vadászati hatósági és kamarai szervezetek az erdészeti hatósággal összefogva tájékoztassák a hasonló problémákkal, illetve talán lehetőségekkel bíró kistérségeket, lássák el szakmai tanácsokkal a térségbeli erdő- és vadgazdálkodókat.

Megítélése sZerint (SZEKRÉNYES 2013) a szajkó helyi védettsége csökkentheti a feszültségeket.

\section{CSELEKVÉSI TERV}

\subsection{CÉLKITÜZÉS}

A magyar vadgazdálkodás - benne az apróvad-gazdálkodás - célja az apróvad populációk egyedszámának és a fajok elterjedési területének növekedését. Ennek a célnak a megvalósításához az élőhelyek védelmén, fejlesztésén és a dúvadfajok állományszabályozásán keresztül vezet az út. A szárnyas dúvadfajok, azaz a varjúfélék szabályozása a fészkelö vadászható és természetvédelem alatt álló madárfajok támogatását szolgálja (FARAGÓ \& NÁHLIK 1997). Közülük helyenként fontos szerepe lehet a szajkópopulációk kezelésének, szabályozásának.

A szajkó korábban egész évben vadászható faj volt Magyarországon, amit az EU madárvédelmi irányelv - fészkelő populáció védelme - alapján július 1. - február 28(29). közti időszakra kellett módosítani. E jogi változásnak fészkelési időszakon belüli kedvezőtlen 
következményei - mind a vadgazdálkodás, mind a természetvédelem területén, a faj madárfészekben okozott kártétele miatt -áthidalására, a vadászati rendelet, apróvadas vadászterületeken, az apróvad szaporodási időszakában, a vadászati hatóság külön engedélyéhez kötve lehetővé teszi gyérítését.

Rövidtávú cél, a jelenlegi szajkópopulációk csökkentése vagy szinten tartása a hazai elterjedési terület egészén. Közép- és hosszútávon, olyan szajkóállomány-kezelési programot kell megvalósítani, amely alacsony egyedszámú, de önfenntartó állománnyal - a faj megőrzése mellett - biztosítja a természetvédelem és a szárnyasvadgazdálkodás eredményességét,.

Vadvédelmi kötelezettségünknek megfelelöen célfeladatként kell kezelni a szajkóállományok szabályozását elsősorban természetvédelmi, másodsorban mind apróvadvédelmi megfontolásból. Erdömüvelési szempontból azonban lokálisan mérlegelni kell a szabályozás mértékét mindaddig, amíg az erdőfelújulásban nyújtott támogatása számottevö lehet.

\subsection{FELADATOK}

\subsection{1. Állományszabályozás szükségessége és jogi keretei}

A célkitüzésekben megfogalmazott rövid-, közép- és hosszú távú célok a fenntartható predátor szabályozást erősítik. Rövidtávú cél, a jelenlegi szajkópopulációk célszerü csökkentése a hazai elterjedési terület egészén. Közép- és hosszútávon, olyan szajkóállománykezelési programot kell megvalósítani, amely alacsony egyedszámú, de önfenntartó állománnyal biztosítja a természetvédelem és a szárnyasvad-gazdálkodás eredményességét, a faj megörzése mellett.

Magyarország EU tagságából adódóan a szajkó és összességében a vadászható varjúfélék vadászatára az Európai Parlament és a Tanács a vadon élő madarak vélelméről szóló 2009/147/EK irányelve (a továbbiakban Madárvédelmi Irányelv) rendelkezései az irányadók, amelyek beépültek a vad védelméröl, a vadgazdálkodásról, valamint a vadászatról szóló 1996. évi LV. törvénybe (a továbbiakban Vtv.) és az annak végrehajtásáról szóló 79/2004 (V.4.) FVM rendeletbe (a továbbiakban Vhr.). A hivatkozott jogszabályok egyértelmüen rendelkeznek a vadászható fajok köréről, a vadászati módokról és idényekről.

Magyarország, a Madárvédelmi Irányelv 7. cikk (3) bekezdése, valamint a II. melléklet $B$ része alapján azon tagállamok közé tartozik ahol a szarka, a dolmányos varjú és a szajkó, valamint a vetési varjú vadászata engedélyezhetö. A Vhr. 1. § (1) bekezdés bb) 9-11. pontjai alapján az elsö három faj vadászható, egyúttal a (2) bekezdés alapján közösségi jelentőségü vadászható fajnak minösül, míg a védett és a fokozottan védett növény- és állatfajokról, a fokozottan védett barlangok köréröl, valamint az Európai Közösségben természetvédelmi szempontból jelentős növény- és állatfajok közzétételéről szóló 13/2001. (V. 9.) KöM rendelet 2. számú mellékletében felsorolt vetési varjú védett.

A Madárvédelmi Irányelv 7. cikk (4) bekezdése alapján a hatályos nemzeti elöírások szerint történö vadászat meg kell, hogy feleljen az ésszerü hasznositás és az ökológiailag kiegyensúlyozott állományszabályozás elveinek, továbbá a vadászható fajok esetében is biztosítandó, hogy azokat ne lehessen sem a fészekrakás, sem a fiókanevelés, vagy a szaporodás különböző szakaszaiban vadászni. Előzőeknek megfelelöen a Vtv. 28. § (4) bekezdésének a) pontja általánosan tiltja a madárfajok fészkének és fészkelésének zavarását, megrongálását, vagy elpusztítását, míg a 38.§ (4) bekezdése alapján a vadászható madárfajok egyedeire, a fészekrakás és fiókanevelés időszakában, illetve a szaporodási időszakban - 
vonuló fajok esetében a fiókanevelési területükre történő visszatérésük során történő vadászatot. A Vhr. 5. számú mellékletében megállapitott vadászati idénye a vadászható varjúféléknek a hivatkozott rendelkezésekkel összhangban július 1-én kezdödik és február utolsó napjáig tart.

Figyelemmel kell azonban arra is lenni, hogy a Madárvédelmi irányelv 1. cikkében meghatározottak szerint az a tagállamok Szerződésben érintett európai területén természetesen előforduló összes vadon élő madárfaj védelmére vonatkozik. Továbbá arra is, hogy a 2. cikk alapján szükséges az 1. cikkben meghatározott fajok állományait megfelelö szinten fenntartani, vagy olyan szintre hozni, amely megfelel különösen az ökológiai, tudományos és kulturális követelményeknek, figyelembe vége a gazdasági és rekreációs követelményeket is, ezért szükségessé válhat a varjúfélék gyérítése a vadászati idényen kívüli időszakban is.

A szarka, a dolmányos varjú, és a szajkó idényen kívüli vadászatát a Vtv. 38. § (3) bekezdésének b) pontjára alapozottan a vadászati hatóság - közösségi jelentöségü vadászható vadfaj vonatkozásában a 38/A. § (1)-(3) bekezdésében foglaltak szerint engedélyezheti, egészen pontosan a Vhr. 27. § (7) bekezdésében foglaltaknak megfelelöen, apróvadas vadászterületeken, az apróvad szaporodási idöszakában. Ezen rendelkezés, összhangban áll a Madárvédelmi irányelv 9. cikk (1) bekezdése alatt meghatározott feltétellel, amely kimondja, „ha nincs más megfelelő megoldás” a tagállamok „eltérhetnek az 5-8. cikk rendelkezéseitől az a), b) és c) pontok alatt felsorolt okok miatt, amelyeket a Vtv. 38/A. § (1) bekezdésének a) f) pontjai tartalmaznak. Tételesen felsorolva ezek a következők:

a) közegészségügyi, illetve közbiztonsági okból,

b) a légi közlekedés biztonsága érdekében,

c) a növényi kultúrák, a termés, az állatállomány, az erdők, a halállományok, a vizek súlyos károsodásának megelőzése érdekében,

d) kutatás és oktatás, állományfeljavítás, visszatelepítés és az ezekhez szükséges tenyésztés céljából,

e) egyes vadászható madárfajok - az érintett állomány nagyságához mérten kisszámú szelektív befogásának, tartásának, illetve hasznosításának érdekében, vagy

f) a vadon élő állatok és növények, valamint a természetes élőhelyek védelme érdekében.

A vadgazdálkodás és a természetvédelem számára legfontosabb a felsorolt indokok között a vadon élő növény- és állatvilág védelme érdekében engedélyezett eltérési lehetőség (lásd Vhr. 27. § (7) bekezdése), ami jelentős mértékben járulhat hozzá a fészkelő védett madárfajok (valamint az apróvad) megőrzési erőfeszítéseinek sikeréhez. Az idényen kívüli vadászat engedélyezéséről szóló hatósági döntésnek a Vtv. 38/A § (2) bekezdés a) - e) pontjai szerint meg kell határoznia

a) a vadfajt és az egyedek számát,

b) a befogás vagy elejtés módját, eszközeit,

c) azt a területet, amelyen a tevékenység gyakorolható,

d) a tevékenység időtartamát, és

e) a tevékenység vadászati hatóság általi ellenőrzésének módját.

Előzőeken túlmenően, az engedélyes a tevékenység végrehajtásáról a vadászati hatóságnak, míg utóbbi a földmüvelésügyi miniszternek tartozik beszámolási kötelezettséggel, aki a természetvédelemért felelős miniszter útján (ez jelen esetben ugyanaz a személy) - közösségi jelentőségű vadászható vadfaj - esetében kétévente (derogációs) jelentést küld az Európai bizottság részére. 
A Vtv. 30. § (1) bekezdése rendelkezik arról, hogy a vadat elejteni, elfogni, kizárólag a törvényben meghatározott módon szabad, egyúttal tiltja a méreg alkalmazását. Utóbbi tiltás alól ugyanezen jogszabályhely (2) bekezdése ad felmentést, azzal a kitétellel, hogy - közösségi jelentőségü vadászható vadfaj vonatkozásában a 38/A. § (1)-(3) bekezdésében foglaltak szerint - a mérgező hatású anyagok használatára vonatkozó külön jogszabályok figyelembevételével engedélyezhetö szelektív méreg alkalmazása. A Vhr. 60. § (2) bekezdése szerint a szelektív hatású vegyszer abban az esetben használható többek között dolmányos varjú, szarka és szajkó elpusztítására, amennyiben az védett állatot nem veszélyeztet. Mivel mind a holló, mind pedig a vetési varjú védett, kézenfekvőbb a varjúfélék gyérítését csapdázásra alapozottan végezni.

A Vtv. 67§ (3) kezdése a vad elfogását az e célra szolgáló hálóval, befogó karámmal, altató-, bénító-lövedékes fegyverrel, valamint a vonatkozó közösségi rendeletben nem tiltott, illetve megengedett csapdázási módszerrel teszi lehetővé. A Madárvédelmi Irányelv 8. cikke és IV. melléklete alatt meghatározott tiltott befogási eszközöket és módszereket a Vtv. 68. § (1) bekezdésének f) és g) pontjai, valamint a Vtv. 71. § (2) bekezdésének f), g), j) 1) és m) pontjai tartalmazzák. Előbbi jogszabályhelyek tiltják a hurok, a horog, a madárlép, valamint a müködése, vagy felhasználása körülményei folytán nem szelektív háló alkalmazását. Az utóbbi rendelkezések szerint pedig a vadászat rendje megsértésének minősül a vad megtévesztésére szolgáló elektronikus akusztikai eszköz, vagy mesterséges anyag, valamint a vak és megcsonkított élő csali-állat, a tükör és más vakító eszköz, a mérgezett vagy altató csalétkek, továbbá a madarak tömeges, vagy nem szelektív befogását, vagy elpusztítását eredményező, illetve a fajok helyi eltünését eredményező csapdázási eszköz, illetve eljárás és módszer.

Tekintettel az élő csali-állat gyakori alkalmazására meg kell említeni, hogy a Madárvédelmi Irányelv 6. cikk (1) bekezdésére alapozottan, a Vhr. 45. § (2) bekezdése nem engedi többek között a dolmányos varjú, a szarka és a szajkó élö, vagy elpusztult, illetve elejtett egyedeinek és származékainak vagy könnyen felismerhető részeinek eladását, eladásra történő szállítását, eladásra történő tartását, valamint eladásra történő felkínálását sem.

\subsubsection{Az állományszabályozás ideje}

A szajkó állományszabályozását a VT. végrehajtási rendelete határozza meg. Július 1. - február 28(29). közötti időszakban gyéríthető (lőhető, csapdázható). A fészkelési időszak (mind a szajkó, mind a zsákmányolt madárfajok esetében) kizárása kedvezőtlen hatásokkal járna mind a vadgazdálkodás, mind a természetvédelem számára - a faj madárfészekben okozott kártétele miatt -, de a vadászati rendelet, apróvadas vadászterületeken, az apróvad szaporodási időszakában, a vadászati hatóság külön engedélyéhez kötve lehetővé teszi gyérítését.

A mezei területeken megvalósitott jó gyakorlat (2. ábra) azt mutatja, hogy egész évben kell a szabályozást folytatni, de különösen az augusztus-február idöszak a hatékony.

\subsubsection{Az állományszabályozás eszköztára}

\subsubsection{Fegyveres szabályozás}

A fegyveres szabályozás folytatható egész évben, de egyes időszakokban az eltérő módszerek hatékonysága eltérő, illetve kizárólagos lehet.

A mủuhuval való vadászat inkább a kóborlás időszakában lehet eredményes. Rendkívül fontos a hivatásos (és sport) vadászok esetében a löjellel való elszámolás, annak 
nyilvántartása. A szajkószabályozás lőjelek utáni premizálása (lőszer, vagy pénz) a hajlandóságot erösíti, és a hatékonyságot növeli.

Jelentőség: Magas (8-10)

Hatékonyság: Magas (8-10)

Ütemezés: Egész évben

Felelős: megyei vadászati hatóságok

Együttmüködők: OMVV területi szervezetei, vadgazdálkodók, nemzeti parkok

\subsubsection{2. Élve fogó csapdázás}

A varjúfélék csapdázása általánosan elterjedt vadgazdálkodási és természetvédelmi gyakorlat, amelyet Európa mindegyik vadászati kultúrkörébe tartozó területen alkalmaznak. Eredményességét több szerző pl. StubBE (1977), THE GAME CONSERVANCY (1989), TAPPER et al. (1991), FARAGÓ (1997), WESTERKAMP (2006), HAJAS (2009) és KARLSSON (2009) is említi.

A LARSEN csapda (Hajas, 2007, 2011) és a svéd Trolle-LJUngbY L84 csapda (KARLSSON 2009; HAJAS, 2012) a tavasszal territóriumot foglaló és párba állt szajkók (illetve más varjú-félék) gyérítésének eszközei (4. ábra).

Mind a LARSEN- és a Trolle-LJUNGbY L84, mind pedig a létrás csapdához élö csalimadár használatára van szükség.

A csalimadarak számára kellő takarást, ülő rudat, valamint tiszta vizet és állati fehérjében dús takarmányt kell biztosítani. Az állatjóléti szempontokon túlmenően, a hatékonyság szempontjából is fontos, hogy a csalimadarak kondíciója jó legyen, ugyanis a leromlott állapotú „,betolakodó” nem jelent kihívást a territóriumát védő pár számára. Esős időszak során a csalimadarakat a számukra kialakított, nagyobb mozgást és szárítkozást lehetővé tévő röpdében kell tárolni, amely szolgálhat a befogott madarak egy részének átteleltetésére is, hogy könnyebben lehessen megkezdeni a rákövetkező év tavaszán induló csapdázási kampányt. Egy röpdében csak egy fajhoz tartozó csalimadarakat szabad tárolni.

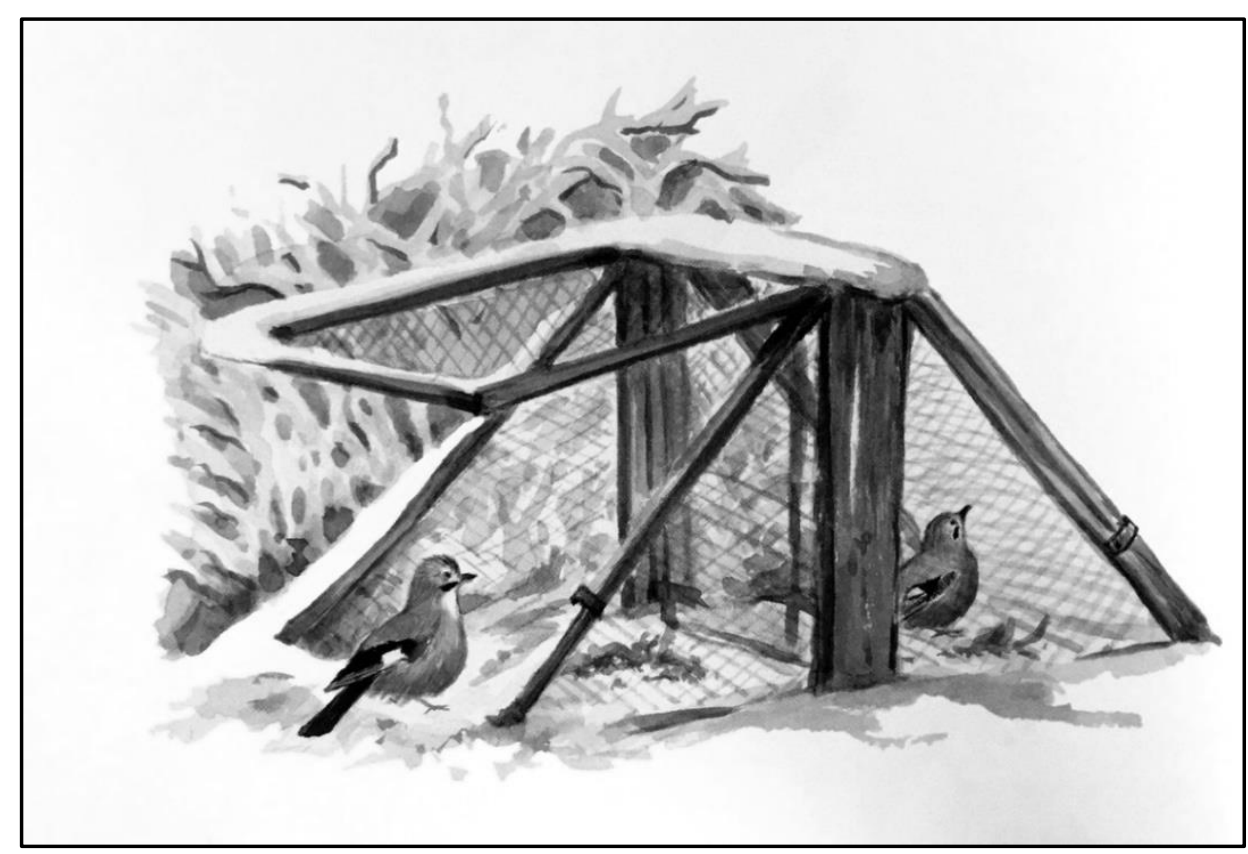

4. ábra: Hatékony szajkócsapda: TROLLE-LJUNGBY L84 svéd csapda (KARLSSON 2009) Figure 4: Effective Eurasian Jay trap: TROLLE-LJUNGBY L84 type Swedish trap (KARLSSON 2009) 
A szajkó csapdázásának fő időszaka március 1. és április 15. közé esik, emiatt minden esetben rendelkezni kell idényen kívüli vadászatra szóló engedéllyel. Amennyiben a társfészkelő fajok számára fontos a fészkek rendbetétele, a szaporodási időszak elején még nem, csak a költési időszak kezdetével szabad a csapdázást megkezdeni. Általában a tojókat sikerül elsőként megfogni, amelyekkel a csalimadarat kicserélve a párjuk is megfogható.

Az élő csali mellett a fent leírt okokból a fogórekeszekben egy-egy tojást, vagy más táplálékforrást kell elhelyezni. Amint a territoriális pár egyedeit a fészek közelében elhelyezett csapdával sikerült megfogni, azt tovább lehet mozgatni.

A varjúfélék csapdázására használt eszközöket a tanulás és a csapdához való hozzászokás elkerülése érdekében lehetőleg a madarak aktív időszakán kívül, kora hajnalban, vagy az esti órákban kell telepíteni és ellenőrizni. Kötelező a napi rendszerességgel történő ellenörzés!

A csapdákkal megfogott nem célfajok egyedeit, eltérő módon rendelkező engedély hiányában a befogás helyén, az észlelést követően haladéktalanul szabadon kell engedni. A megfogott szajkókat kíméletesen és gyorsan kell elpusztítani.

Jelentőség: Magas (9-10)

Hatékonyság: Magas (9-10)

Ütemezés: évente március 1. és május 31. között

Felelős: FM Erdészeti és Vadgazdálkodási Főosztály, megyei vadászati hatóságok

Együttmüködők: vadgazdálkodók, Országos Magyar Vadászati Védegylet

\subsubsection{A szabályozás természetvédelmi vonatkozásai}

A szajkóállomány szabályozásának egyik leghatékonyabb eszköze a fészkelő állomány alacsony szinten tartása. Ebben az időszakban a legintenzívebb ugyanis a fészek-predációja más, rendszerint védett madárfajok fészkeinél. Erdei (nagyvadas) területeken szabályozásának kizárólagos célja a madárfajok fészkeinek védelme. Mezei területeken hozzávehetjük a vadászható fajok fészek-predációjának

Jelentőség: Magas (8-10)

Hatékonyság: Közepes (6)

Ütemezés: folyamatos

Felelős: megyei vadászati és természetvédelmi hatóságok

Együttmüködők: OMVV és területi szervezetei, vadgazdálkodók, OMVK és területi szervezetei, nemzeti parkok

\subsubsection{Tanácsadás vad- és erdőgazdálkodók, természetvédők számára}

A hivatásos vadász valamint természetvédelmi őri továbbképzéseken meg kell ismertetni a gazdálkodókkal és területkezelőkkel a szajkó tényleges gazdálkodási jelentőségét, predációs súlyát, egyszersmind az erdőtelepítésben betöltött lokális lehetséges szerepét.

Jelentőség: Közepes (6)

Hatékonyság: Közepes (6)

Ütemezés: Költési és fiókanevelési időszak előtt, évente ismételve

Felelős: megyei vadászati hatóságok, Országos Magyar Vadász Kamara

Együttmüködők: vadgazdálkodók, erdőgazdálkodók, természetvédelem 


\subsubsection{Oktatás és továbbképzés}

A szajkó szabályozására vonatkozó ismeretek oktatása és annak folyamatos aktualizálása fontos az alap-, közép- és felsőfokú vadgazdálkodási (és természetvédelmi) szakemberképzésben. Az oktatást végző intézmények tananyagai, tankönyvei és jegyzetei tartalmazzák a predátor gazdálkodás elméleti és gyakorlati ismeretanyagát. A vadgazdálkodási szakemberek rendszeres továbbképzései során ugyancsak ismertetni kell szabályozás célkitüzéseit, módszereit és eredményeit.

Jelentőség: Magas (8-10)

Hatékonyság: Közepes (6)

Ütemezés: Folyamatosan

Felelős: OMVV, OMVK országos és megyei területi szervezetei, SoE-EMK Vadgazdálkodási és Gerinces Állattani Intézet

Együttmüködő: szakirányú képzést folytató alap-, közép- és felsőfokú oktatási intézmények

\subsubsection{Kutatás és monitoring}

A kutatásnak a faj hazai jobb megismerését szolgáló célt kell szolgálnia. Ezek főbb elemei a következök:

- Populáció diszperziója, szaporodási viszonyai

- Táplálkozása megváltozott körülmények között

- Élőhely-monitoring (fészkelöhely, táplálkozóhely)

- Csapdázási eredményesség elemzése

Jelentőség: Közepes (6)

Hatékonyság: Közepes (6)

Ütemezés: Folyamatosan

Felelős: SoE-EMK Vadgazdálkodási és Gerinces Állattani Intézet

Együttmüködő: más felsőoktatási intézmények, vadgazdálkodók

\subsubsection{Kommunikáció és nyilvánosság}

\subsubsection{Kommunikáció az érintett hatóságokkal}

A predátor (benne a szajkó) állományok szabályozásának hatékonysága érdekében a vadgazdálkodóknak jó kapcsolatokat kell kialakítani valamennyi, annak sikerességét elősegítő hatósággal:

- megyei vadászati hatóságok

- FM Erdészeti és Vadgazdálkodási Főosztály

- NÉBIH

- természetvédelemért felelős hatóságok

Jelentőség: Magas (8-10)

Hatékonyság: Jó (8)

Ütemezés: Folyamatosan

Felelős: FM Erdészeti és Vadgazdálkodási Főosztály 


\subsubsection{Kommunikáció a nagyközönséggel}

Kellö rendszerességgel tájékoztatni kell a nagyközönséget a dúvadszabályozás szükségességéröl és helyzetéről.

Különösen fontos a nagyközönséggel megismertetni az írott és elektronikus médián keresztül a dúvadszabályozás szerepét, fontosságát és szabályozottságát. A kommunikáció súlyát növeli annak állatvédelmi vonzatai miatt. Kiemelt jelentősége van a helyi sajtón, információs anyagokon, plakátokon keresztüli tájékoztatásnak.

Jelentőség: Magas (8)

Hatékonyság: Közepes (6)

Ütemezés: Aktualitások figyelembe vételével, évente ismételve

Felelős: Földművelésügyi Minisztérium, megyei Kormányhivatalok, OMVV, OMVK, SoEEMK Vadgazdálkodási és Gerinces Állattani Intézet

\subsubsection{Felülvizsgálat}

A Szajkó Kezelési Terv megvalósítását évente áttekinti az Országos Vadgazdálkodási Tanács, és állásfoglalása alapján értékeli az FM Erdészeti és Vadgazdálkodási Főosztálya, amely azután - ha a szükség úgy kívánja - meghozza a szükséges intézkedéseket.

\section{3. ÖSSZEFOGLALÁS}

\section{1. ÁLLOMÁNYSZABÁLYOZÁSI HELYZET}

A 2000-es évek első évtizedében 58 000-81000 párban adták meg a hazai fészkelő szajkópopulációt (MME NOMENCLATOR BIZOTTSÁG, 2008). A korábban ennél lényegesen magasabb állomány elsősorban a kémiai szerekkel történő szabályozás hatására csökkent le. Napjainkban 15-20000 példányos terítéke a madárvédelmi és apróvad-gazdálkodási feladatok teljesítéséhez valószínüleg nem elégséges (az 1970-es 1980-as évek fordulóján 3035000 példányos volt éves terítéke).

\subsection{KEZELÉSI PRIORITÁS}

A szajkó, mint az erdei madárfajok egyik legfontosabb fészekpredátora, valamint az erdőkkel határos területek mezei madárfajainak (főként fácán és fogoly) potenciális zsákmányolója a vadgazdálkodási intézkedések tekintetében arányosan magas prioritást érdemel.

\subsection{CÉLOK}

Rövidtávon, a jelenlegi szajkópopulációk célszerü csökkentése a hazai elterjedési terület egészén. Közép- és hosszútávon, olyan dúvadszabályozási programok megvalósítását kell szorgalmazni, amelyek lehetővé teszik a populációk egyedszámának alacsony szinten tartását, figyelembe véve az esetleges ettől eltérő lokális erdőgazdálkodási érdekeket.

\section{4. ÁTFOGÓ KEZELÉSI POLITIKA}

Prioritás kell, hogy legyen a dúvadszabályozás - lelövéssel és csapdázással. 


\subsection{CSELEKVÉSI TERV}

\section{1. Élőhely-gazdálkodás}

C1.1. A dúvad-gazdálkodást kiemelten kell kezelni, és az éves tervekben rögzíteni kell elöírásait. A hatósági munka során érvényt kell szerezni betartásuknak.

Nagy jelentőségü, hatékony. Felelös szervezet: megyei vadászati hatóságok,OMVV megyei szervezetei

\section{Politika és jogalkotás}

C.2.1. Biztosítani kell a csapdázás és a szelektív gyérítési eljárások jogi és gazdasági feltételeit.

Nagy jelentőségö, hatékony. Felelős szervezet: FM Erdészeti és vadgazdálkodási Föosztály

\section{Tanácsadás, oktatás}

C3.1. Minden lehetséges módon (a hivatásos vadász és természetvédelmi örtovábbképzéseken) meg kell ismertetni a gazdálkodókkal a szajkó (általában a dúvad fajok) tényleges vadgazdálkodási jelentőségét, predációs súlyát, szabályozásának jogi lehetőséget, technikai eszköztárát és a jó gyakorlatot. Be kell mutatni a faj esetleges lokális erdészeti jelentőségét is.

Nagy fontosságú, nagy hatékonyságú. Felelös: OMVV, OMVK országos és megyei területi szervezetei, SoE-EMK Vadgazdálkodási és Gerinces Állattani Intézet.

\section{Kutatás és monitoring}

A kutatás során az alábbi prioritásokat kell szem előtt tartani:

C.4.1. Populáció diszperziója, szaporodási viszonyai

C.4.2 Táplálkozása megváltozott körülmények között

C.4.3. Élőhely-monitoring (fészkelőhely, táplálkozóhely)

C.4.4. Csapdázási eredményesség elemzése

Nagy fontosságú, közepes hatékonyságú. Felelös: Földmüvelésügyi Minisztérium, megyei vadászati hatóságok, SoE-EMK Vadgazdálkodási és Gerinces Állattani Intézet, SZIE Vadvilág Megörzési Intézet

\section{Kommunikáció és nyilvánosság}

C.5.1. A dúvadgazdálkodás hatékonysága és elfogadtatása érdekében a vadgazdálkodásnak jó kapcsolatokat kell kialakítani valamennyi hatósággal.

Nagy jelentöségü, nagy hatékonyságú. Felelös: FM, Kormányhivatalok

C.5.2. Kellő rendszerességgel tájékoztatni kell a nagyközönséget a dúvadgazdálkodás fontosságáról, helyzetéről.

Nagy fontosságú, közepes hatékonyságú. Felelös: megyei vadászati hatóságok, OMVV, OMVK, SoE-EMK Vadgazdálkodási és Gerinces Állattani Intézet, SZIE Vadvilág Megörzési Intézet 


\section{FELHASZNÁLT IRODALOM}

BANKOvics A. \& VADÁsz Cs. (2009): Szajkó - Garrulus glandarius (Linnaeus, 1758). In: CsÖrGŐ T., KARCZA Zs., Halmos G., MAGYAR G. GYURÁCZ J., SzÉP T., BANKOVICS A., SCHMIDT A. \& SCHMIDT E. (szerk.): Magyar madárvonulási atlasz. Kossuth kiadó. pp. 572-573.

BEJĆEK V. \& GoRBAn I. (1997): Jay - Garrulus glandarius In: HAGEMEIJER, W. J. M. \& BLAIR, M. J. (szerk.): The EBCC Atlas of European Breeding Birds: Their distribution and abundance. T and D Poyser, London. 670-671 pp.

BirdLife InTERnAtional (2004): Birds in Europe. Population estimates, trends and conservation status. Cambridge, UK: BirdLife International (BirdLife Conservation Series No. 12.). 374 p.

CHERNEL I. (1899): Magyarország madarai különös tekintettel gazdasági jelentőségökre. Második könyv, Budapest. 830 p.

ChERnel I. (1921): A szajkó Garrulus glandarius L. károsságához. Aquila 28: 166-167.

CsÁNYI S. (szerk.)(2001): Vadgazdálkodási Adattár - 2000/2001. vadászati év. Országos Vadgazdálkodási Adattár, Gödöllö.

CsÁNYI S. (szerk.)(2005): Vadgazdálkodási Adattár - 2004/2005. vadászati év. Országos Vadgazdálkodási Adattár, Gödöllő.

CSÁNYI S. (2015)(szerk.): A 2014/2015. vadászati év vadgazdálkodási eredményei valamint a 2015. tavaszi vadállomány-becslési adatok és vadgazdálkodási tervek. Országos Vadgazdálkodási Adattár, Gödöllö. 152 p.

CsÁNyi S., LeHOCZKY R. \& SONKOly K. (szerk.) (2005): Vadgazdálkodási Adattár 2005/2006. vadászati év. Országos Vadgazdálkodási Adattár, Gödöllő. 64 p.

CSÁNYI S., LEHOCZKY R. \& SONKOLY K. (szerk.) (2008): Vadgazdálkodási Adattár 2007/2008. vadászati év. Országos Vadgazdálkodási Adattár, Gödöllő. 64 p.

CSÁNYI S., LEHOCZKY R. \& SONKOLY K. (szerk.) (2010): Vadgazdálkodási Adattár 2009/2010. vadászati év. Országos Vadgazdálkodási Adattár, Gödöllő. 56 p.

CsÁNYi S., LEHOCZKY R. \& SONKOLY K. (szerk.) (2012a): Vadgazdálkodási Adattár 2010/2011. vadászati év. Országos Vadgazdálkodási Adattár, Gödöllő. 52 p.

CsÁNyi S., LEHOCZKY R. \& SONKOLY K. (szerk.) (2012b): Vadgazdálkodási Adattár 2011/2012. vadászati év. Országos Vadgazdálkodási Adattár, Gödöllő. 52 p.

CsáNyi S., Tóth K. \& Schally G. (szerk.) (2012b): Vadgazdálkodási Adattár - 2012/2013. vadászati év. Országos Vadgazdálkodási Adattár, Gödöllő. 52 p.

CsÁNyi S., TóTH K., KovÁCs I. \& SCHALly G. (szerk.) (2014): Vadgazdálkodási Adattár 2013/2014. vadászati év. Országos Vadgazdálkodási Adattár, Gödöllő. 48 p.

CsÁNYi S., KovÁcs I., CsóKÁs A., PUTz K. \& Schally G. (szerk.) (2015): Vadgazdálkodási Adattár - 2014/2015. vadászati év. Országos Vadgazdálkodási Adattár, Gödöllő. 36 p.

CsÁNYi S., KovÁcs I., CsóKÁs A., Putz K. \& SCHAlly G. (szerk.) (2016): Vadgazdálkodási Adattár - 2015/2016. vadászati év. Országos Vadgazdálkodási Adattár, Gödöllö, 48 pp.

CSIKI E. (1913): Biztos adatok madaraink táplálkozásáról VIII. Aquila 20: 375-396.

FARAGÓ S. (1997): Élöhelyfejlesztés az apróvad-gazdálkodásban. A fenntartható apróvadgazdálkodás környezeti alapjai. Mezőgazda Kiadó, Budapest. 356 p.

FARAGÓ S. (2001a): Adatok a magyarországi mezei szárnyasvad fajok fészekalj nagyságaihoz és tojásméreteihez. Magyar Apróvad Közlemények 6: 113-132.

FARAGÓ S. (2001b): Mezei szárnyasvad fajok vonulása Magyarországon, jelölt madarak megkerülése alapján. Magyar Apróvad Közlemények 6: 133-161.

FARAGÓ S. (2015): Vadászati állattan. Negyedik, átdolgozott kiadás. Mezőgazda Kiadó Budapest. 542 p. 
FARAGÓ S., JÁNOSKA F., DitTRICH G. \& GICZI F. (2012): Varjúfélék (Corvidae) állomány- és teríték monitoringja a LAJTA Projectben. In: FARAGÓ, S. (szerk.): A LAJTA Project. Egy tartamos mezei vad és ökoszisztéma vizsgálat 20 éve. Nyugat-magyarországi Egyetem Kiadó, Sopron. pp. 353-363.

FARAGÓ S. \& NÁHLIK A. (1997): A vadállomány szabályozása. A fenntarható vadgazdálkodás populációökológiai alapjai. Mezőgazda Kiadó, Budapest. 315 p.

FESTETICS J. (1954): Adatok varjú-féléink fészkeléséhez. Aquila 55-58: 261+305.

GLUTZ von Blotzheim, U. N. \& BAUER, K. M. (1993): Handbuch der Vögel Mitteleuropas. Band 13/III. Passeriformes (4. Teil Corvidae - Sturnidae). Aula Verlag, Wiesbaden.

Hajas P. P. (2007): Csapdázással a Fogoly Repatriációs Program sikeréért. Nimród Vadászújság 95 (11): 21.

HAJAS P. P. (2009). Az élvefogó csapdák alkalmazásának tapasztalatai a szőrmés és szárnyas kártevők korlátozásában. In: NAGY, E. (szerk.): Vadgazdálkodásunk fejlesztésének lehetöségei. A vadgazdálkodás idöszerü kérdései 9. pp. 59-64.

HAJAS P. P. (2011): Oldalajtós Larsen-csapda. Magyar Vadászlap 20 (4): 267.

HAJAS P. P. (2012): A Larsen-csapda északi változata: Trolle-Ljungby L84. Magyar Vadászlap 21 (5): 316.

HARASZTHY L. (2019): Szajkó Garrulus glandarius (LinNAEUS, 1758). In: HARASZTHY L.: Magyarország fészkelö madarainak költésbiológiája. 2. kötet. Sárgarigóféléktöl a sármányfélékig (Passeriformes). Pro Vértes Nonprofit Zrt., Csákvár: 53-57.

HARRISON, C. (1975): Jungvögel, Eier und Nester aller Vögel Europas, Nordafrikas und des Mittleren Ostens. Verlag Paul Parey, Hamburg und Berlin.

HERMAN O. (1901): A madarak hasznáról és káráról. Budapest, 280 p.

JonssOn L. (1993): Birds of Europe with North-Africa and Middle East. C. Helm Publisher Ltd/A. \& C. Black Publisher Ltd. London.

KARLSSON B. (2009). Fångst av kråkfåglar. Svenska jägareförbundets Förlag, Stockholm

Keve A. (1967): A délnyugati szajkó a magyar faunában. Aquila 73-74: 75-79.

Keve A. (1995): Der Eichelhäher. Die Neue Brehm Bücherei 410., 4. unveränd. Auflage, Westarp Wissenschaften - Magdeburg, Spektrum Akademischer Verlag, Heidelberg Berlin - Oxford, 119 p.

Keve-Kleiner A. (1942): A szajkók kóborlása Magyarországon 1939-40. év telén. Aquila 4649: 366-372.

Keve A. \& SterbetZ I. (1968): Über die Nahrung des Eichelhähers. Der Falke 6 (6-7): 184$187 \& 230-233$.

KoRodi GÁl J. (1972): Beiträge zur Kenntnis der Brutbiologie und Brutnahrung der Eichelhäher (Garrulus glandarius). Trav. Mus. Antipa 12: 355-383.

LOBODA ST. (2002): „Oberforstmeister” Eichelhäher geehrt. AFZ-Der Wald 26: 1412.

LOVASSY S. (1927): Magyarország gerinces állatai és gazdasági vonatkozásaik. Királyi Magyar Természettudományi Társulat, Budapest. 895 p.

MAdGe S. (2017). Eurasian Jay (Garrulus glandarius). In: DEL HoYo, J., ElliotT, A., Sargatal, J., Christie, D.A. \& DE JuAna, E. (eds.): Handbook of the Birds of the World Alive. Lynx Edicions, Barcelona. (retrieved from http://www.hbw.com/node/60727 on 24 May 2017).

Magyar G., Hadarics T., WAlicZKy Z., SchmidT A. \& BAnKovics A. (1998): Nomenclator Avium Hungariae. Magyarország madarainak névjegyzéke. Madártani Intézet - MME - Winter Fair, Budapest-Szeged. 202 p.

MaKatsch W. (1976): Die Eier der Vögel Europas. Band 2. Neumann Verlag, LepzigRadebeul. 460 p. 
MME NOMENClAtOR BizOTTSÁG (2008): Magyarország madarainak névjegyzéke. Nomenclator avium Hungariae. An annotated list of the birds of Hungary. Magyar Madártani és Természetvédelmi Egyesület, Budapest. 278 p.

MME (2017): Magyarország madarai: Szajkó.

http://www.mme.hu/magyarorszagmadarai/madaradatbazis-gargla Letöltés dátuma: 2017-05-25

MÖDLINGER P. (1975): Szajkók (Garrulus glandarius) a Budapesti Állatkert felett. Aquila 8081: 292.

NEMESKÉRI KISS G., FÉLIX E. \& GLÓSER D. (1942): A hivatásos vadász. I. kötet. 375 p.

PÁtKAi I. (1971): Szajkó (Garrulus g. glandarius) In: SÁRKÁNY P. \& VAllus P. (szerk.): A vadászat kézikönyve. Mezőgazdasági Kiadó, Budapest, 191 pp.

RozGONYI S. (1994): Szarka (Pica pica) fészkében költő szajkó (Garrulus glandarius). Madártani Tájékoztató 1994. Okt.-Dec.: 35-36.

SCHMIDT E. (1989): A szajkók (Garrulus glandarius) számának emelkedése a Gellérthegyen. Madártani Tájékoztató 1989. Júl.-Dec.: 38-39.

StubBe M. (1977). Raubwild, Raubzeug, Krähenvögel. Deutscher Landswirtschaftsverlag, Berlin, $206 \mathrm{p}$.

SZEKRÉNYES T. (2011): A szajkó (Garrulus glandarius) szerepe a Balaton-felvidéki pusztuló feketefenyvesek lombos erdővé történő természetes átalakulásában. Magyar Apróvad Közlemények 11: 29-48.

SzEMERE L. (1957): A szajkó gombaevése. Aquila 63-64: 296+349.

SzÉCSI Zs. (1892). A vadászati ismeretek kézikönyve. II. kötet. A hazai vadak természetrajza. Budapest, Grill Károly cs. és kir. udvari könyvkereskedése. 286 p.

TAPPER, S., SWAN, M. \& REYNOLDS, J. (1991): Larsen Traps: A survey of members' results. The Game Conservancy Review of 1990, Vol. 22., pp. 82-86.

The Game Conservancy (1989): Predator and squirrel control. Sahara Publications Ltd. London. 74 p.

TÖRÖK J. (2000): Szajkó - Garrulus glandarius In: HARASZTHY L. (szerk.): Magyarország madarai. Mezőgazda Kiadó. Második, javított kiadás. 349-350 pp.

TUCKer, G. M. \& HeATH, M. F. (1994): Birds in Europe: their conservation status. Cambridge, U.K. BirdLife Conservation Series 3.

VARGA F. (1994): Holló (Corvus corax) fészkét kifosztó szajkó (Garrulus glandarius). Madártani Tájékoztató 1994. Jan. - Jún.: 4-5.

VASVÁRI M. (1933): A szajkók táplálkozása és vándorlása. Az Erdö 7: 15-18.

WesterkamP A. (2006). Fangjagd. Franckh-Kosmos Verlags GmbH \& Co. KG. Czech Republic

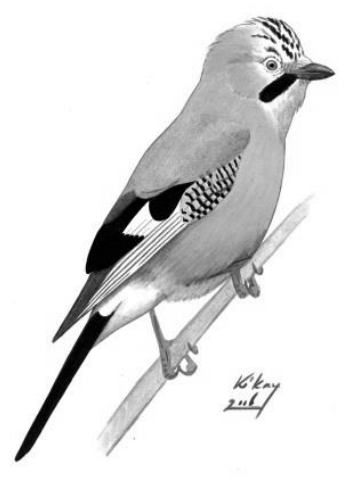

